(C) 2021, The Authors. Published by Elsevier Inc. and Fass Inc. on behalf of the American Dairy Science Association ${ }^{\circledR}$. This is an open access article under the CC BY-NC-ND license (http://creativecommons.org/licenses/by-nc-nd/4.0/).

\title{
Effect of 3 autumn pasture management strategies applied to 2 farm system intensities on the productivity of spring-calving, pasture-based dairy systems
}

\author{
S. H. Evers, ${ }^{1,2 *} \odot$ L. Delaby, ${ }^{3} \oplus$ C. Fleming, ${ }^{1}$ K. M. Pierce,${ }^{2} \oplus$ and B. Horan ${ }^{1} \oplus$ \\ ${ }_{1}^{1}$ Animal and Grassland Research and Innovation Centre, Teagasc Moorepark, Fermoy, Co. Cork, P61 C996, Ireland \\ ${ }^{2}$ School of Agriculture and Food Science, University College Dublin, Belfield, Dublin 4, Ireland \\ ${ }^{3}$ INRAE, L'institut Agro, Physiologie, Environnement et Génétique pour l'Animal et les Systèmes d'Elevage, F-35590 Saint-Gilles, France
}

\begin{abstract}
The objective of this study was to investigate the effect of altering autumn pasture availability and farm system intensity on the productivity of spring-calving dairy cows during autumn. A total of 144 HolsteinFriesian and Holstein-Friesian $\times$ Jersey crossbred dairy cows were randomly assigned to 2 whole farm system (FS) intensities and 3 autumn pasture availability (PA; measured above $3.5 \mathrm{~cm}$ ) treatments in a $2 \times 3$ factorial arrangement. The 2 farm systems consisted of a medium intensity (MI: 2.75 cows/ha, target postgrazing sward height of $4.0-4.5 \mathrm{~cm}$ ) and high intensity system (HI: 3.25 cows/ha, target postgrazing sward height of $3.5-4.0 \mathrm{~cm},+1.8 \mathrm{~kg}$ of concentrate dry matter [(DM)/ cow per day]. Within each farm system treatment, cows were further subdivided into 3 different PA management strategies: high PA (HPA), medium PA (MPA), and low PA (LPA). The experimental period lasted for 11 wk from September 1 to housing of all animals on November 20 ( \pm 2 d) over 3 yr (2017-2019, inclusive). To establish the different average pasture covers for each PA treatment during autumn and in particular at the end of the grazing season, grazing rotation length was extended by +13 and $+7 \mathrm{~d}$ for HPA and MPA, respectively, beyond that required by LPA ( $37 \mathrm{~d}$ ). There were no significant FS $\times \mathrm{PA}$ interactions for any of the pasture, dry matter intake, or milk production and composition variables analyzed. There were also no differences in pregrazing sward characteristics or sward nutritive value between FS with the exception of daily herbage allowance, which was reduced for HI system (12.2 vs. $14.2 \mathrm{~kg}$ of DM/cow). Milk and milk solid yield were greater for HI groups (15.9 and $1.55 \mathrm{~kg} /$ cow per day, respectively) compared with MI (15.4 and $1.50 \mathrm{~kg} /$ cow per day, respectively). Mean paddock pregrazing herbage mass was significantly higher with increased PA ranging from a mean of $1,297 \mathrm{~kg}$ of DM/ha for LPA
\end{abstract}

Received July 8, 2020.

Accepted February 3, 2021.

*Corresponding author: sophie.evers@teagasc.ie to 1,718 and $2,111 \mathrm{~kg}$ of $\mathrm{DM} /$ ha of available pasture for MPA and HPA, respectively. Despite large differences in pregrazing herbage mass, there was no difference in cumulative pasture production and only modest differences in grazing efficiency and sward nutritive value between PA treatments. On average, closing pasture covers were 420,650 , and $870 \mathrm{~kg}$ of DM/ha for LPA, MPA, and HPA, respectively, on December 1. In addition to maintaining similar grazing season lengths and achieving big differences in availability of pasture on farm into late autumn, PA treatment had no significant effect on dry matter intake, milk production, and body condition score during the study period. The results of this study indicate that greater cow performance and pasture utilization can be achieved through a greater daily concentrate allocation along with an increased stocking rate. Moreover, the potential to adapt grazing management practices to increase the average autumn pasture cover in intensive grazing systems is highlighted. In addition, a high dependence on high-quality grazed pasture during late autumn can be ensured without compromising grazing season length while also allowing additional pasture to be available for the subsequent spring.

Key words: intensive pasture-based dairy system, autumn pasture management, feed budget, farm system

\section{INTRODUCTION}

Improving the efficiency of agricultural systems worldwide is a significant challenge for the future to reconcile the growing global food requirement with the necessity for more climate, ecosystem, and animal-friendly production practices (Godfray and Garnett, 2014; Delaby and Horan, 2017; Clay et al., 2020). The general shift to more intensive livestock production systems worldwide has also occurred in grassland systems, resulting in elevated stocking intensities and an increasing reliance on inorganic fertilizers and nonpasture supplementation (Ramsbottom et al., 2015; Stott and Gourley, 2016; Ma et al., 2018). Despite this intensification, the continuing role of grasslands in efficiently converting 
human inedible feed to high-quality human food is acknowledged (Peyraud, 2017; Mottet et al., 2017), and further improvements of grazing systems in Europe are considered as a primary opportunity to develop more climate-smart food systems for the future (EU, 2019). The success of such systems is predicated on increasing overall pasture productivity while also maintaining a high proportion of grazed pasture in the total animal diet over a long grazing season, and thereby, reducing the requirement for exogenous supplementary feed inputs (Macdonald et al., 2017; Delaby and Horan, 2017).

To capture the maximum benefits of grazed pasture, having the correct number of cows per unit area of land (stocking rate; SR) calving compactly at the beginning of the pasture growth season, is widely acknowledged as the main driver of productivity within grazing systems. The decision rules describing optimum SR and calving pattern have been comprehensively described (Hoden et al., 1991; McCarthy et al., 2013; Roche et al., 2017). The recent general trend toward intensification of grazing systems via increasing SR places added feed demands on the available land area and can result in increased feed supplementation and a shortening of the grazing season when pasture supply is limited (McCarthy et al., 2012; Stott and Gourley, 2016; Roche et al., 2017). On that basis, and as grazing systems become more intensive, grazing management strategies including feed budgeting, grazing rotation planning, and grazing intensity must also be adapted to optimize the productivity of more intensive systems to support the increased feed demands of grazing animals during periods of pasture deficits.

Sufficient pasture availability in the spring is a result of a comprehensively managed autumn feed budget. The importance of greater pasture availability in the spring has been widely substantiated (Kennedy et al., 2005; Claffey et al., 2020). The historical approach both in research and on commercial farms to improve available pasture in the spring, was to alter autumn closing and housing dates (Carton et al., 1988; Roche et al., 1996) as earlier closed swards resulted in greater pasture production for the subsequent spring (Hennessy et al., 2006; Lawrence et al., 2017). However, at farm level, there has been resistance among farmers to increase overall pasture supply and pregrazing herbage mass (HM) during autumn due to the perceived detrimental effects on pasture utilization and animal performance (Hanrahan et al., 2017). Moreover, the shortening of the grazing season in autumn in favor of additional pasture availability in spring also reduces grazing season length and increases the requirements for supplementary feed to replace pasture in the late lactation diet of animals (Roche et al., 1996; Claffey et al., 2020). Hence, the provision of additional pasture in the spring was given priority over extended grazing during late autumn (Carton et al., 1988; Ryan et al., 2010; Lawrence et al., 2017). Detailed sward nutritive value evaluations have also revealed that, although earlier housing in autumn can substantially increase spring pasture availability, at least some of the potential benefits of additional spring pasture are negated by elevated postgrazing heights, increased herbage senescence, and reduced sward nutritive value (Tuñon et al., 2014; Beecher et al., 2015). Nonetheless, the substantial economic benefits of extending grazing season length in both autumn and spring have been quantified (Läpple et al., 2012; Hanrahan et al., 2018). On that basis, the further appraisal of opportunities to increase pasture availability at both extremities of the grazing season while maintaining sward nutritive value and animal performance merits further evaluation.

The objective of this study was to evaluate the potential for 3 adapted pasture availability (PA) strategies within 2 levels of farm system intensity to deliver the advantages of extended grazing in late autumn while maintaining sward quality and animal performance and conserving adequate pasture for timely turnout in spring. Our hypotheses were that (1) extended grazing season in late autumn for higher SR systems can be sustained with additional concentrate supplementation coupled with the achievement of a lower postgrazing sward height (PGSH) and (2) strategically increasing PA from late summer by extending rotation length can maintain animal performance on a predominantly pasture-based diet into late autumn while also accumulating sufficient pasture for the grazing season ahead. For this, first, the effect of farm system (FS) with regards to increasing SR $(+0.5$ cows/ha) and concentrate supplementation $(+1.8 \mathrm{~kg}$ of DM/cow per day) in combination with a greater pasture utilization $(-0.5 \mathrm{~cm}$ PGSH $)$ was investigated, and second, target closing pasture covers for differing PA treatments were achieved by altering the grazing rotation length throughout autumn accordingly.

\section{MATERIALS AND METHODS}

This experiment was the first part of a larger systems experiment investigating the biological and economic effect of alternative SR and pasture management combinations on animal and pasture performance, and environmental and economic efficiency, undertaken at the Animal and Grassland Research and Innovation Centre, Teagasc Moorepark, Ireland $\left(50^{\circ} 7 \mathrm{~N} ; 8^{\circ} 16 \mathrm{~W}\right)$, over a 3 -yr period $(2017,2018$, and 2019 inclusive). The measurement period consisted of $11 \mathrm{wk}$, starting in the 
first week of September and concluding at the end of grazing season in the third week of November.

\section{Experimental Farm System Design, Treatments, and Animals}

The experiment was a randomized block design with a $2 \times 3$ factorial arrangement of treatments. There were two whole farm systems intensities: medium intensity (MI; 2.75 cows/ha plus $90 \%$ pasture diet) and high intensity (HI; 3.25 cows/ha and $80 \%$ pasture diet). The MI farm system was designed to allow individual cows to achieve a high level of daily herbage allowance (DHA; measured above $3.5 \mathrm{~cm}$ ) and milk production per cow, whereas the HI farm system was designed to investigate the potential to increase pasture utilization and milk production per hectare through increased SR and grazing intensity while maintaining total individual feed allowance per cow using additional concentrate supplementation. To each farm system, 3 PA treatments [low (LPA), medium (MPA), and high (HPA)] were assigned and designed to achieve target closing average PA levels of 400,600, and $800 \mathrm{~kg}$ of DM/ha (available above $3.5 \mathrm{~cm}$ ) at the end of grazing season on December 1 for LPA, MPA, and HPA, respectively. The LPA treatment group was designed to reflect prevailing pasture management practice on Irish commercial dairy farms based on current Irish national autumn pasture data statistics (PastureBase Ireland; Hanrahan et al., 2017). In contrast, the MPA treatment was designed to reflect current best practice recommendations (Tuñon et al., 2014) based on previous studies, proposing a closing cover for December 1 of $600 \mathrm{~kg}$ of DM/ha for farms that have an SR of approximately 2.5 cows/ ha (Teagasc, 2009) and was therefore considered the control PA. Finally, HPA represents a further incremental increase in autumn PA, which may be appropriate within more intensive higher SR dairy production systems during autumn.

All PA treatments were managed similarly throughout the main grazing season. To achieve the desired differences in PA on December 1, grazing rotation length was extended by $2 \mathrm{~d}$ per week from July 15 , August 1, and August 15 for the HPA, MPA, and LPA, respectively. In consequence, the target average peak autumn PA for October 8 was 75, 100, and $125 \%$ of recommended peak PA (equivalent to 750, 1,000, and $1,250 \mathrm{~kg}$ of DM/ha of pasture available) for LPA, MPA, and HPA, respectively. Thereafter, the differences in PA created were maintained until the end of the grazing season.

A total of 144 cows were used in each year of the experiment. The experimental herd was comprised of high Economic Breeding Index (EBI) Holstein-Friesian and Holstein-Friesian $\times$ Jersey Crossbred animals with average EBI, milk, fertility, calving, maintenance, management, and health subindices of €159, 52, 58, 39, 26, 3 , and 2 , respectively. Each year, cows were randomly assigned precalving based on expected calving date, breed, parity, genetic merit (EBI), BW, and BCS to one of the 6 autumn experimental treatments. The mean (and standard deviation) for calving date, parity, precalving BW, and BCS were February 20 ( \pm 19.9 d), $3.2( \pm 1.70)$ lactations, $555 \mathrm{~kg}( \pm 79.6) \mathrm{BW}$, and 3.1 $( \pm 0.272)$ BCS units, respectively. At the end of lactation in late autumn, animals were then sequentially dried off based on expected calving date (primiparous animals were dried off for a minimum of $70 \mathrm{~d}$ and multiparous animals for $56 \mathrm{~d})$, BCS ( $\leq 2.75$ units) and milk yield $(<8 \mathrm{~kg} /$ cow per day).

\section{Grazing Area, Grazing Management, and Feed System}

The experimental site soil type was a free-draining, acid brown soil with a sandy loam to loam texture. A total of 48 ha of permanent grassland were divided into 17 discrete land blocks of uniform character, giving a total of 102 paddocks. The paddocks were balanced for location, sward species, soil type, and distance to the milking parlor. The swards on the farm were predominantly made up of at least $80 \%$ perennial ryegrass ( $\mathrm{Lo}$ lium perenne L.) and white clover (Trifolium repens L.). All 6 treatments were allocated an equal grazing area (8 ha), and to create the difference in SR between FS, there were 22 cows in each MI group and 26 cows in HI to achieve overall SR of 2.75 and 3.25 cows/ha, respectively. Thus, cows from the MI and HI farm systems within each PA treatment grazed in adjacent paddocks of the same size to facilitate common rotation lengths, herbage biomass supply, and paddock residency duration. Each farmlet remained in the same treatment for the duration of the experiment and received an annual chemical $\mathrm{N}$ fertilizer application of $250 \mathrm{~kg}$ of $\mathrm{N} /$ ha per year. Between August 1 and September 15, 2 fertilizer applications were applied to all PA treatments, containing approximately 17 and $33 \mathrm{~kg}$ of N/ha each.

Average pasture cover for each PA treatment was measured on a weekly basis using visual estimation methods as described by O'Donovan et al. (2002). No swards were topped (mechanically conditioned) during the experiment, and all pasture surpluses were conserved as pasture silage. Animals were offered fresh pasture on a 24 -h or 36 -h basis over the main grazing season as part of a rotational-stocking system when weather conditions allowed. Where necessary, 12-h 
grazing allocations and on-off grazing (Kennedy et al., 2009) were practiced to facilitate grazing during periods of inclement weather. During wet weather, back fences were used to minimize damage to paddocks, and animals were housed during periods of severe rainfall and allocated an equal amount of pasture silage.

Due to the higher SR and the similar area allocation and thereby reduced DHA, all HI groups received an additional daily allocation of $1.8 \mathrm{~kg}$ of $\mathrm{DM} /$ cow of concentrate for the duration of the experiment to achieve a similar total feed allowance, a lower PGSH in each paddock $(-0.5 \mathrm{~cm})$, and a similar residency time to MI. Decisions on the level of concentrate supplementation to MI groups were made weekly based on achieving target PA each week culminating in the target closing PA on December 1. Consequently, concentrates were introduced for all 6 treatments when average pasture cover for MPA was below target. Likewise, when pasture cover exceeded target levels, concentrates were reduced or removed. In yr 1, cows were allocated $97 \mathrm{~kg}$ of DM of concentrate for MI and $235 \mathrm{~kg}$ of DM for HI, compared with 298 and $430 \mathrm{~kg}$ of DM, respectively, in yr 2, and 159 and $288 \mathrm{~kg}$ of DM, respectively, in yr 3. Where specific feed shortages occurred for LPA or HPA groups, conserved forage was used to supplement feed supply and recorded for each PA group individually. Similarly, when pasture availability exceeded demand within a specific PA treatment, paddocks from that treatment were conserved for silage. All silage yields were recorded.

\section{Herbage Measurements}

Pregrazing HM (cut to approximately $3.5 \mathrm{~cm}$ ) was determined before each grazing in all paddocks for each of the 6 treatments by harvesting a strip $(1.2 \times 10 \mathrm{~m})$ of pasture with an Etesia mower (Etesia UK Ltd.) at 11 am daily preceding grazing. All mown herbage from each strip was collected and weighed, a $0.1 \mathrm{~kg}$ (fresh weight) subsample was taken and dried for $16 \mathrm{~h}$ at $90^{\circ} \mathrm{C}$ for DM determination (Beecher et al., 2013) and another $0.3 \mathrm{~kg}$ (fresh weight) subsample was taken for further chemical analysis. Ten compressed sward height (CSH) measurements were recorded before (precutting $\mathrm{CSH}$ ) and after (postcutting CSH) harvesting on each cut strip using a folding pasture plate meter with a steel plate (Jenquip Rising Plate Meters; diameter 355 $\mathrm{mm}$ and $\left.3.2 \mathrm{~kg} / \mathrm{m}^{2}\right)$.

Herbage mass was calculated as outlined by O'Donovan et al. (2002):

$$
\begin{gathered}
\text { Herbage mass }(\mathrm{kg} \text { of } \mathrm{DM} / \mathrm{ha})=\text { Fresh weight }(\mathrm{kg}) \\
\times \text { area }(\text { length } \times 1.2 \mathrm{~m}) \times 10,000 \times \mathrm{DM} \% / 100
\end{gathered}
$$

Sward density was calculated, using the measurement below (Delaby and Peyraud, 1998):

$$
\begin{aligned}
& \text { Sward density }(\mathrm{kg} \text { of } \mathrm{DM} / \mathrm{cm} \text { per hectare })= \\
& \text { Herbage mass }(\mathrm{kg} \text { of DM/ha)/ } \\
& \text { (precutting CSH - postcutting CSH). }
\end{aligned}
$$

Pregrazing sward height and PGSH were determined for each paddock before and after grazing by taking 30 CSH measurements across the diagonal of the paddock. The average paddock pregrazing HM was corrected to $3.5 \mathrm{~cm}$ by the equation of Delaby and Peyraud. (1998):

Pregrazing HM $(\mathrm{kg}$ of DM/ha) =

[Pregrazing sward height $(\mathrm{cm})-3.5 \mathrm{~cm}$ ]

$\times$ sward density ( $\mathrm{kg}$ of $\mathrm{DM} / \mathrm{cm}$ per hectare).

Daily herbage allowance was calculated based on residency time within each paddock and above a cutting height of $3.5 \mathrm{~cm}$ using the measurements below:

$$
\begin{gathered}
\text { DHA }(\mathrm{kg} \text { of DM/cow per day })=\text { area }(\text { ha } / \mathrm{d}) \\
\times \text { pregrazing HM }(\mathrm{kg} \text { of } \mathrm{DM} / \mathrm{ha}) / \text { number of cows. }
\end{gathered}
$$

Total herbage removed and individual daily herbage removed (DHR) were calculated above the actual PGSH recorded after grazing with the following formulas:

Total herbage removed $(\mathrm{kg}$ of $\mathrm{DM} / \mathrm{ha})=$

(Pregrazing sward height $-\mathrm{PGSH}) \times$ sward density

$$
\begin{gathered}
\text { DHR }(\mathrm{kg} \text { of } \mathrm{DM} / \text { cow per day })= \\
\text { area }(\text { ha } / \mathrm{d}) \times \text { total herbage removed } \\
(\mathrm{kg} \text { of } \mathrm{DM} / \mathrm{ha}) / \text { number of cows. }
\end{gathered}
$$

The efficiency of grazing was also determined using the method of Delaby and Peyraud (1998) based on the following formula:

$$
\begin{gathered}
\text { Grazing efficiency }(\%)=\text { total herbage removed/ } \\
\text { pregrazing HM. }
\end{gathered}
$$

Total pasture production per hectare per year was calculated as the pregrazing HM minus the postgrazing $\mathrm{HM}$ of the previous rotation as determined by the method outlined by O'Donovan et al. (2002). Daily pasture growth rates were then calculated by dividing the herbage accumulated by the interval between grazings. 


\section{Chemical Analysis}

Herbage samples were collected from each paddock for each treatment during the final grazing rotation only (depending on treatment between September 25 and October 9 until housing on November 20) and frozen at $-18^{\circ} \mathrm{C}$. Herbage samples were then bowlchopped, freeze-dried at $-50^{\circ} \mathrm{C}$ for $120 \mathrm{~h}$ and milled through a 1-mm sieve. Samples were analyzed by wet chemistry for ash, ADF, NDF (Van Soest, 1963), CP (Leco FP-428; Leco Australia Pty Ltd.), and organic matter digestibility (OMd) as described by Morgan et al. (1989) and modified by Garry et al. (2018). The energy content of the pasture, expressed as unité fourragère lait, was subsequently calculated as described by INRA (2010).

The concentrate offered was analyzed for DM, ash, $\mathrm{CP}$, and NDF. Where silage was fed to treatments during periods of inclement weather, a sample was collected, dried at $40^{\circ} \mathrm{C}$ for $72 \mathrm{~h}$ and analyzed for DM, ash, ADF, NDF, and $\mathrm{CP}$ and calculated for OMd as outlined by Morgan et al. (1989). The ingredient composition of the concentrate feed was beet pulp 35\%, corn gluten $26 \%$, barley $25 \%$, soybean meal $11 \%$, and minerals plus vitamins 3\%. Mean concentrate quality was $154 \mathrm{~g} / \mathrm{kg}$ of CP, $177 \mathrm{~g} / \mathrm{kg}$ of crude fiber, $105 \mathrm{~g} / \mathrm{kg}$ of ash, and $895 \mathrm{~g} / \mathrm{kg}$ of OM.

\section{Animal Measurements}

DMI. Measurements of individual pasture DMI (PDMI) were estimated using the n-alkane technique (Mayes et al., 1986) as modified by Dillon and Stakelum (1989). Samples for cow PDMI were collected at the beginning of October (experimental wk 6), at the peak of the average pasture cover during autumn. All cows were dosed twice daily, after morning and evening milking with paper bungs containing $500 \mathrm{mg}$ of C32-alkane (n-dotriacontane, an indigestible marker) over a 12-d period. From d 7 to 12 of dosing, fecal samples were collected from each cow twice daily before morning and evening milking and stored at $-20^{\circ} \mathrm{C}$. The fecal samples were subsequently thawed, bulked (12 $\mathrm{g}$ of each collected sample) and dried for $48 \mathrm{~h}$ in a $40^{\circ} \mathrm{C}$ oven in preparation for chemical analysis. Selected herbage samples were manually collected daily on d 6 to 11 (inclusive) with Gardena hand shears (Accu 60, Gardena International $\mathrm{GmbH}$ ) and cut to the PGSH following the PGSH observations of the grazing dairy cows. The ratio of herbage C33-alkane (tritriacontane) to dosed C32-alkane was used to estimate DMI. The $n$-alkane concentration was determined as outlined by Dillon (1993).
Milk Production. Cows were milked twice daily throughout lactation across the $3 \mathrm{yr}$ of the experiment. The milking process was carried out at 0700 and 1530 h daily. Weekly milk production was derived from individual cow milk yield $(\mathrm{kg})$ recorded at each milking (Dairymaster). Milk fat, protein, and lactose concentration for each cow was determined weekly from successive p.m. and a.m. milkings using a Milkoscan 203 (Foss Electric) and subsequently, weekly solids-corrected milk (SCM; Tyrrell and Reid, 1965), fat, protein, lactose, and MS yields were calculated. Only cows with a minimum lactation duration of $10 \mathrm{wk}$ were kept for analysis ( $\mathrm{n}=140,130$, and 132 in year 1, 2, and 3 respectively). Milk, fat, protein, lactose, and MS yield per hectare (from grazed pasture) were calculated by adding up the total herd daily milk and MS produced from each paddock in each treatment and dividing by the area of the paddock to give the yield per hectare. Similarly, grazing days per hectare was calculated by adding up the total number of cow grazing days in each paddock in each treatment and dividing by the area of the paddock to give the number of grazing days per hectare.

$B W$ and $B C S$. Individual animal $\mathrm{BW}$ and $\mathrm{BCS}$ were recorded fortnightly during the experiment. Body weight was recorded upon exit from the milking parlor using an electronic scale with the Winweigh software package (Tru-Test Limited, https://www.livestock.tru -test.com/en-us/weighing). Animal BCS was measured on a 1 -to- 5 scale $(1=$ thin, $5=$ obese $)$ in increments of 0.25 as outlined by Edmonson et al. (1989). Body condition score was recorded by one individual throughout the experiment.

\section{Statistical Analysis}

Grazing Characteristics and Dietary Details. Grazing data were analyzed from September 1 until housing on November 20 ( \pm 2 d) from all paddocks grazed during each grazing rotation in each year of the experiment. All statistical analyses were carried out using SAS Version 9.4 (SAS Institute Inc.). The effect of year (Y), farm system (FS), pasture availability (PA), and month (M) and their interaction on pasture production, chemical composition of herbage, pregrazing HM, pregrazing sward height, sward density, average residency, DHA, PGSH, postgrazing HM, DHR, grazing efficiency, and concentrate and forage supplementation were analyzed using mixed models (PROC MIXED; SAS Institute, 2010). Year (2017-2019, inclusive), FS (MI and HI), PA (LPA, MPA, and HPA) and month (9-11) were fitted as fixed effects in the model. Paddock was the experimental unit and was included as the random effect in the model. The data are presented 
as the least squares means \pm standard error and were analyzed using the following model:

$$
\begin{gathered}
\mathrm{Y}_{i j k l}=\mu+\mathrm{FS}_{i}+\mathrm{PA}_{j}+\mathrm{Y}_{k}+\mathrm{M}_{l}+\left(\mathrm{FS}_{i} \times \mathrm{PA}_{j}\right) \\
+\left(\mathrm{Y}_{k} \times \mathrm{FS}_{i}\right)+\left(\mathrm{Y}_{k} \times \mathrm{PA}_{j}\right)+\left(\mathrm{Y}_{k} \times \mathrm{FS}_{i} \times \mathrm{PA}_{j}\right)+e_{i j k l},
\end{gathered}
$$

where $\mathrm{Y}_{i j k l}=$ dependent variable; $\mu=$ mean; $\mathrm{FS}_{i}(i=1$ or 2$) ; \mathrm{PA}_{j}=\mathrm{PA}(j=1$ to 3$) ; \mathrm{Y}_{k}=$ year $(k=1$ to 3$) ; \mathrm{M}_{l}$ $=$ month $(l=9$ to 11$) ; \mathrm{FS}_{i} \times \mathrm{PA}_{j}=$ interaction between FS and PA; $\mathrm{Y}_{k} \times \mathrm{FS}_{i}=$ interaction between year and FS; $\mathrm{Y}_{k} \times \mathrm{PA}_{j}=$ interaction between year and PA; $\mathrm{Y}_{k} \times$ $\mathrm{FS}_{i} \times \mathrm{PA}_{j}=$ interaction between year, FS, and PA; and $e_{i j k l}=$ the residual term error.

DMI and Milk Production. The effect of year, FS, PA, parity, breed, experimental week, calving day of the year (CD), genetic merit index (GMI), and their interactions on daily DMI, milk production, SCM, milk fat, protein, and lactose concentrations, fat, protein, lactose, and MS yield per cow were analyzed using mixed models (PROC MIXED; SAS Institute, 2010).

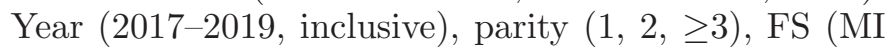
and HI), PA (LPA, MPA, and HPA), and experimental week (1-11) were included as fixed effects. Calving day of the year and the GMI were fitted as continuous covariates. Experimental week was introduced as repeated measures, and a new variable was created as YearCow to take account of multiple lactations for some individual cows and was treated as a random subject. These variables were analyzed using the following model:

$$
\begin{gathered}
\mathrm{Y}_{i j k l m n}=\mu+\mathrm{FS}_{i}+\mathrm{PA}_{j}+\mathrm{B}_{k}+\mathrm{P}_{l}+\mathrm{W}_{m}+\mathrm{Y}_{n} \\
+\mathrm{CD}_{i j k l m n}+\mathrm{GM}_{i j k l m n}+\left(\mathrm{FS}_{i} \times \mathrm{PA}_{j}\right)+\left(\mathrm{Y}_{n} \times \mathrm{FS}_{i}\right) \\
+\left(\mathrm{Y}_{n} \times \mathrm{PA}_{j}\right)+\left(\mathrm{Y}_{n} \times \mathrm{FS}_{i} \times \mathrm{PA}_{j}\right)+e_{i j k l m n},
\end{gathered}
$$

where $\mathrm{Y}_{i j k l m n}$ is the response of animal $h$ of breed $k$, in parity $l$,in FS $i$ and $\mathrm{PA} j$ in year $n ; \mu=$ mean; $\mathrm{FS}_{i}=$ FS $(i=1$ or 2$) ; \mathrm{PA}_{j}=\mathrm{PA}(j=$ to 3$) ; \mathrm{B}_{k}=\operatorname{breed}(k=$ 1 or 2$) ; \mathrm{P}_{l}=$ parity $(l=1,2, \geq 3) ; \mathrm{W}_{m}=$ week $m$ ( 1 to $11) ; \mathrm{Y}_{n}=$ year $(\mathrm{n}=1,2$ or 3$) ; \mathrm{FS}_{i} \times \mathrm{PA}_{j}=$ interaction between $\mathrm{FS}$ and $\mathrm{PA} ; \mathrm{Y}_{k} \times \mathrm{FS}_{i}=$ interaction between year and $\mathrm{FS} ; \mathrm{Y}_{k} \times \mathrm{PA}_{j}=$ interaction between year and $\mathrm{PA} ; \mathrm{Y}_{k} \times \mathrm{FS}_{i} \times \mathrm{PA}_{j}=$ interaction between year, FS and $\mathrm{PA} ; \mathrm{CD}_{i j k l m n}=$ respective $\mathrm{CD} ; \mathrm{GM}_{i j k l m n}=$ respective GMI; and $e_{i j k l m n}=$ the residual term error.

Dry matter intake for pasture and concentrate were analyzed using PROC MIXED in SAS. Treatment (FS and PA), breed, parity, year, and the associated interactions were included in the model. Individual cow was treated as the experimental unit and was included as random effect.
Milk Production and Output per Hectare. Milk yield per hectare, SCM per hectare, fat, protein, lactose yield per hectare and MS yield per hectare, and grazing days per hectare were analyzed with the effect of FS, PA, year, and their interactions included in the model using PROC MIXED procedure in SAS. Paddock was included as the experimental unit and fitted as a random effect. The following model was used:

$$
\begin{gathered}
\mathrm{Y}_{i j k l}=\mu+\mathrm{FS}_{i}+\mathrm{PA}_{j}+\mathrm{Y}_{k}+\mathrm{M}_{l}+\left(\mathrm{FS}_{i} \times \mathrm{PA}_{j}\right) \\
+\left(\mathrm{Y}_{k} \times \mathrm{FS}_{i}\right)+\left(\mathrm{Y}_{k} \times \mathrm{PA}_{j}\right)+\left(\mathrm{Y}_{k} \times \mathrm{FS}_{i} \times \mathrm{PA}_{j}\right)+e_{i j k l},
\end{gathered}
$$

where $\mu=$ mean; $\mathrm{F}_{i}=\mathrm{FS}(i=1$ or 2$) ; \mathrm{PA}_{j}=\mathrm{PA}(j=$ 1 to 3$) ; \mathrm{Y}_{k}=$ year $(k=1$ to 3$) ; \mathrm{M}_{l}=$ month $(l=9$ to 11); $\mathrm{FS}_{i} \times \mathrm{PA}_{j}=$ interaction between $\mathrm{FS}$ and $\mathrm{PA} ; \mathrm{Y}_{k}$ $\times \mathrm{FS}_{i}=$ interaction between year and $\mathrm{FS} ; \mathrm{Y}_{k} \times \mathrm{PA}_{j}=$ interaction between year and $\mathrm{PA} ; \mathrm{Y}_{k} \times \mathrm{FS}_{i} \times \mathrm{PA}_{j}=$ interaction between year, FS, and PA; and $e_{i j k l}=$ the residual term error.

\section{RESULTS}

\section{Meteorological Data}

Although mean annual and autumnal soil temperature and rainfall during the study period were similar to the 10-yr averages (Figure 1), monthly rainfall during the summer of 2018 was significantly below normal (equivalent to $47 \%$ of 10 -yr average values), resulting in significantly reduced summer and autumn pasture growth and greatly increased concentrate supplementation during autumn 2018 for all treatments. Equally, total rainfall during autumn 2019 was $44 \%$ above the 10-yr average (568 and $394 \mathrm{~mm}$, respectively), which also reduced autumn pasture availability and consequently led to a period of additional concentrate and silage supplementation.

\section{Pasture Production, Grazing Characteristics, and Dietary Details During Autumn}

Autumn grazing extended until November $20( \pm 2 \mathrm{~d})$ for each treatment in each of the three study years and resulted in a mean closing pasture cover of 420, 650, and $870 \mathrm{~kg}$ of DM/ha available for LPA, MPA, and HPA, respectively; Figure 2). Year had a significant effect $(P<0.001)$ on all pasture characteristics and in particular the low levels of rainfall during summer and early autumn in yr 2. Total autumn pasture production (from September 1 to December 31) was greatest $(P$ $=0.01)$ in year $1(3,528 \mathrm{~kg}$ of DM/ha) compared with both yr $2(-375 \mathrm{~kg}$ of DM/ha) and yr $3(-613 \mathrm{~kg}$ of $\mathrm{DM} /$ ha, annual and monthly data are not reported). In 
a)

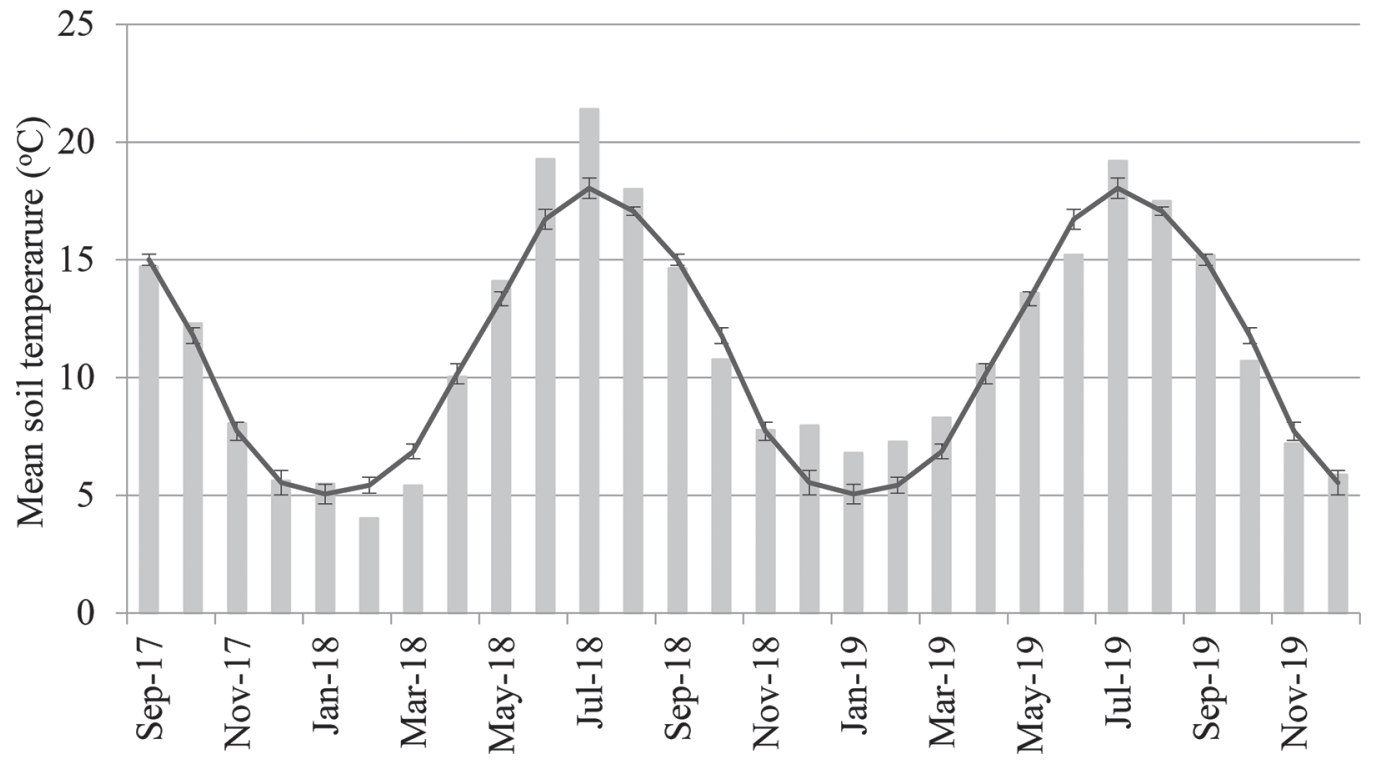

b)

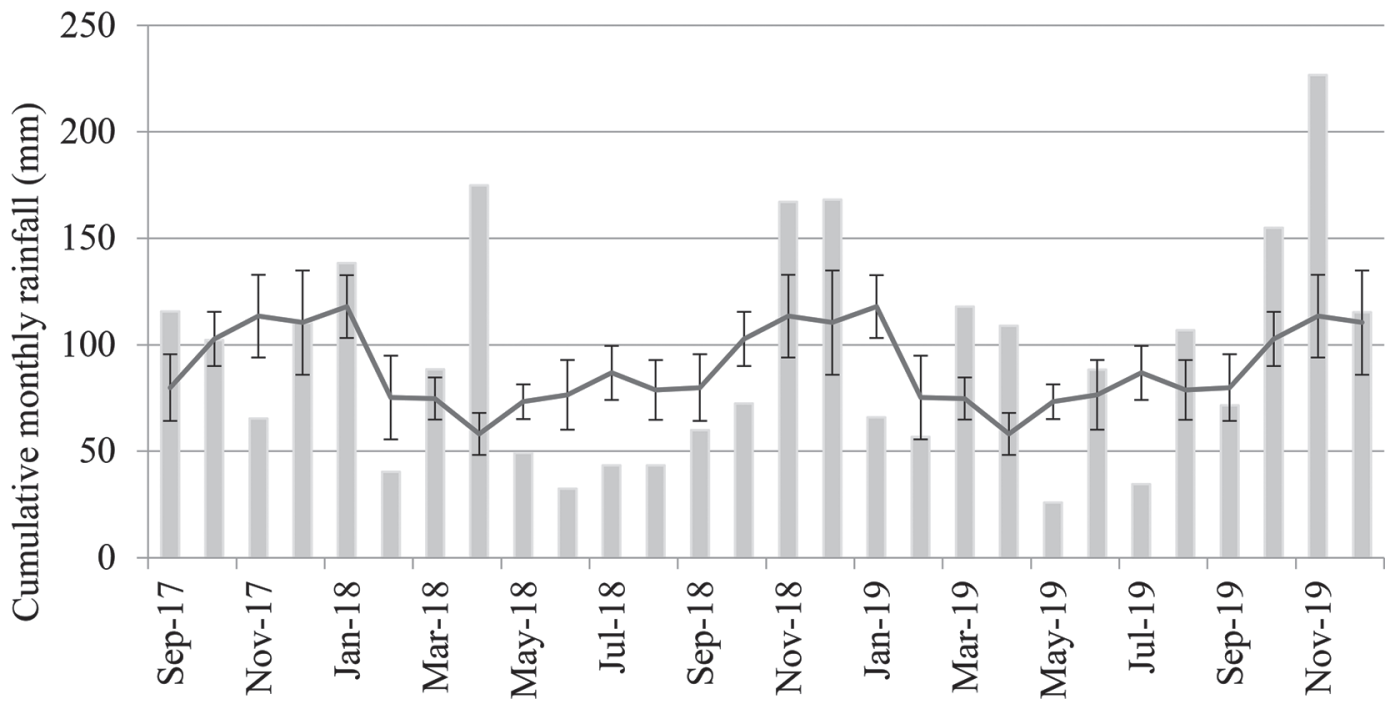

Figure 1. Mean (a) daily soil temperature and (b) cumulative monthly rainfall during the study period compared with the previous 10-yr average (black line) values $( \pm \mathrm{SE})$.

consequence, the greatest average pregrazing HM were recorded during autumn in yr $1(1,941 \mathrm{~kg}$ of DM/ha), whereas the lowest were in yr $2(1,418 \mathrm{~kg}$ of DM/ha), and yr 3 was intermediate $(1,755 \mathrm{~kg}$ of DM/ha). There was a significant effect of month on pasture DM content $(P<0.001)$ and pregrazing HM during autumn. Sward DM content was $16.2,13.9$, and $14.2 \%$, and pregrazing $\mathrm{HM}$ was $1,810,2,000$, and $1,306 \mathrm{~kg}$ of $\mathrm{DM} /$ ha during September, October, and November, respectively.
There was no significant interaction between FS and PA for any of the autumn sward measurements and therefore, only the main effects are presented in Table 1. There were no differences in pregrazing sward characteristics between the FS with the exception of DHA (measured above $3.5 \mathrm{~cm}$ ), which was reduced $(P$ $<0.001)$ for HI (12.2 vs. $14.2 \mathrm{~kg}$ of $\mathrm{DM} / \mathrm{cow})$. As a result of the design of the study, there were also significant differences in PGSH, which was higher $(P<$ 


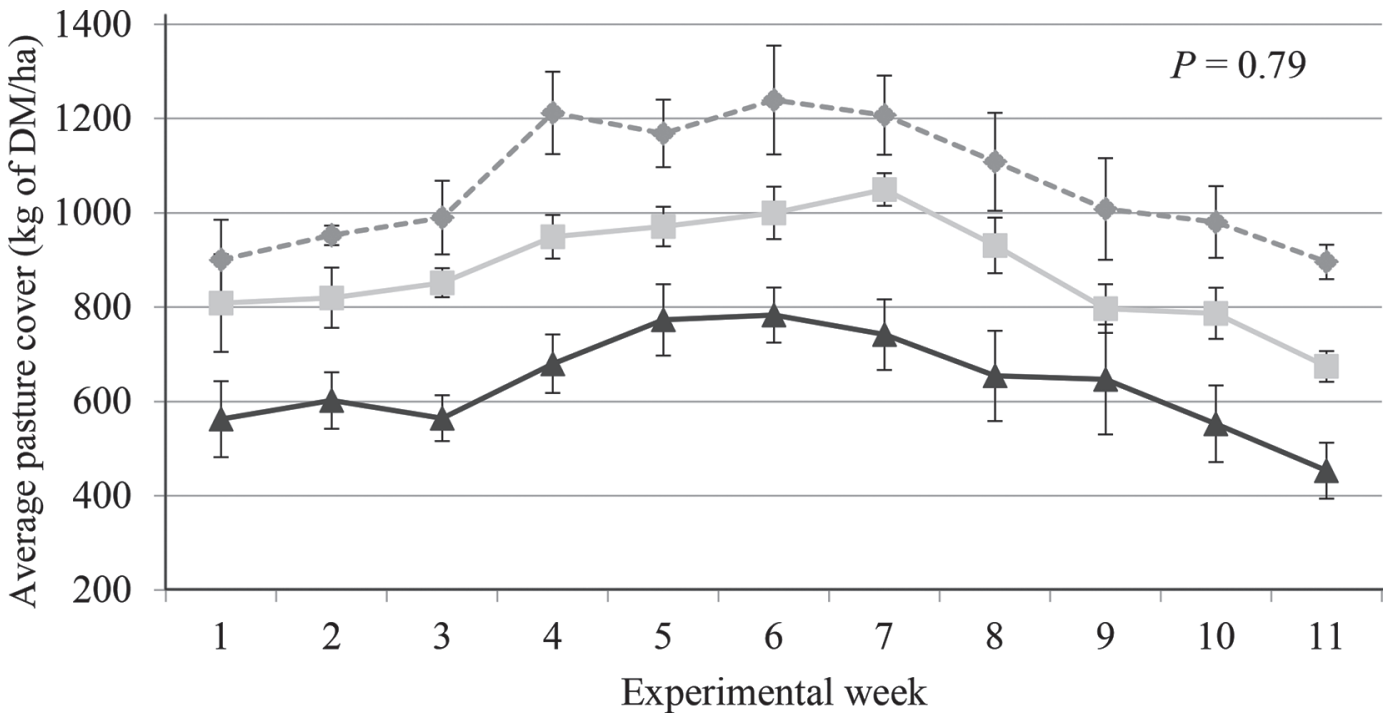

Figure 2. Effect of pasture availability treatment $( \pm \mathrm{SE})$ on weekly average pasture cover during the 11 -wk autumn study period. LPA $=$ low pasture availability $(\mathbf{\Lambda})$; MPA = medium pasture availability $(\mathbf{\square})$; HPA $=$ high pasture availability, $(\bullet)$.

$0.001 ;+0.3 \mathrm{~cm})$ for MI compared with HI, resulting in a higher postgrazing HM and lower grazing efficiency $(P<0.001 ;$ Table 1$)$. Similarly, DHR was greater $(P$ $<0.001)$ for $\mathrm{MI}(+1.4 \mathrm{~kg}$ of $\mathrm{DM} / \mathrm{cow})$ compared with HI. There was also no significant effect of FS on silage supplementation (50 kg of DM/cow); however, the increased daily concentrate allowance for $\mathrm{HI}$ resulted in increased $(P<0.001)$ total concentrate supplementation during autumn compared with MI over the study period (365 vs. $213 \mathrm{~kg}$ of $\mathrm{DM} / \mathrm{cow}$ ).
Autumn grazing rotation length was significantly affected by PA treatment. To establish HPA and MPA, autumn rotation length was extended $(+13$ and $+7 \mathrm{~d}$, respectively) beyond that required by LPA (37 d). The comparably delayed extension of rotation length during late summer for LPA and MPA resulted in small amounts of pasture conservation ( 80 and $55 \mathrm{~kg}$ of DM/ ha, respectively) compared with HPA where no pasture conservation occurred. Mean paddock pregrazing HM and sward height were significantly higher with

Table 1. The effect of farm system (FS) and pasture availability (PA) on autumn pasture characteristics and cumulative supplementary feed requirements ${ }^{1}$

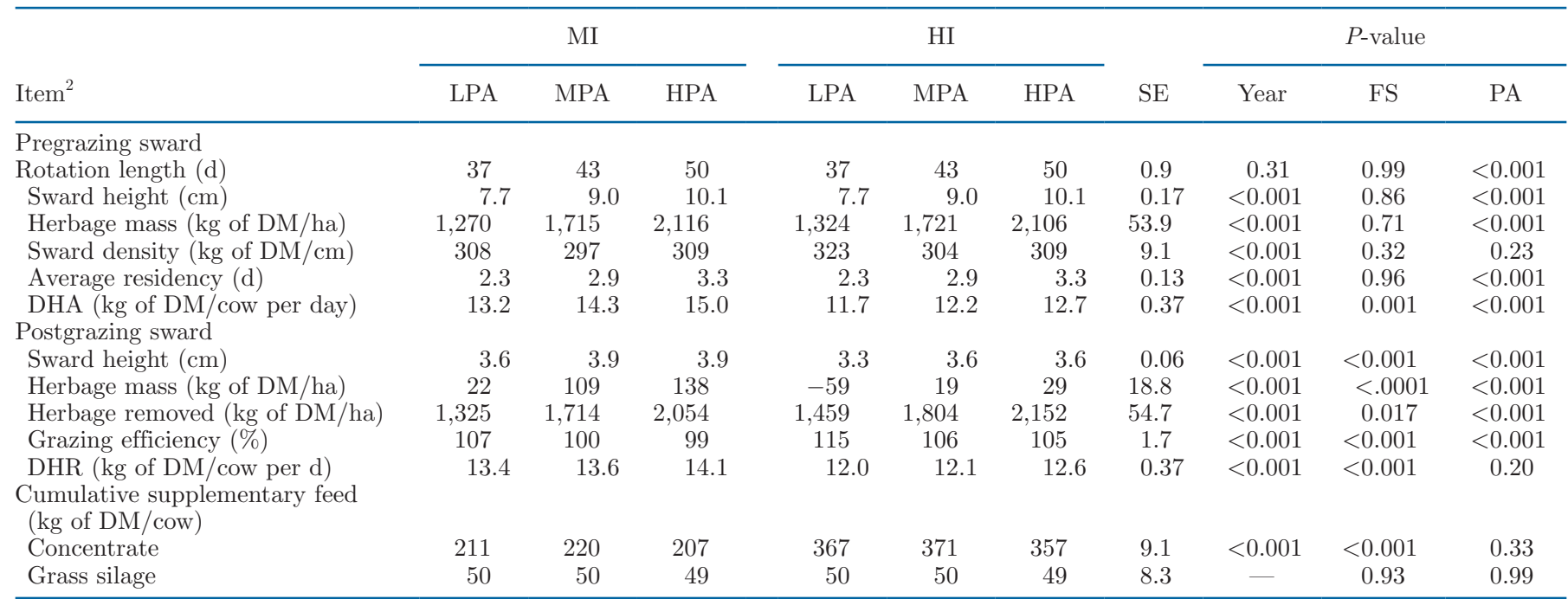

${ }^{1} \mathrm{MI}=$ medium intensity; $\mathrm{HI}=$ high intensity $\mathrm{LPA}=$ low pasture availability; MPA = medium pasture availability; HPA $=$ high pasture availability.

${ }^{2} \mathrm{DHA}=$ daily herbage allowance, measured above $3.5 \mathrm{~cm}$; DHR = daily herbage removed, measured above postgrazing sward height. 
increased PA $(P<0.001)$ ranging from a mean autumn pregrazing $\mathrm{HM}$ of $1,297 \mathrm{~kg}$ of $\mathrm{DM} /$ ha for LPA to 1,718 and $2,111 \mathrm{~kg}$ of DM/ha of available pasture for MPA and HPA, respectively (Table 1 and Figure 2). Despite large differences in pregrazing HM (Figure 3a), there was no difference in sward density between PA treatments. Due to the increased HM in MPA and HPA paddocks, both residency time and DHA increased with increased PA. Total herbage removal ( $\mathrm{kg}$ of $\mathrm{DM} / \mathrm{ha}$ ) increased with increasing PA $(P<0.001 ;+711 \mathrm{~kg}$ of DM/ha for HPA compared with LPA). Postgrazing sward height ranged from 3.4 to $3.7 \mathrm{~cm}$ for the LPA and HPA, respectively (Figure 3b). Similarly, the postgrazing HM was lowest $(-23 \mathrm{~kg}$ of DM/ha) for LPA, intermediate for MPA (57 $\mathrm{kg}$ of DM/ha) and highest for the HPA (74 kg of DM/ ha). In accordance with the PGSH, grazing efficiency was highest for LPA compared with both MPA and HPA $(P<0.001)$. There was no significant effect of PA on DHR (13.0 kg of DM/cow per day), indicating that lower PGSH adjusted for the lower DHA between treatments. There was no significant effect of PA treatments on grazed or total pasture production $(3,230 \mathrm{~kg}$ of DM/ha; Table 2). As per the experimental design, there was no difference $(P>0.1)$ in concentrate and silage supplementation per cow between PA treatments during autumn with low levels of both concentrate (260 $\mathrm{kg}$ of $\mathrm{DM} / \mathrm{cow}$ ) and silage (50 kg of DM/cow) required to maintain all groups on a grazing diet until late autumn each year.

Sward quality parameters were unaffected by FS during autumn, and there were also no significant interactions between FS and PA. However, PA had a significant effect on sward quality during autumn (Table 3; Figure 4). Both, sward OMd $(P=0.002)$ and $\mathrm{CP}$ content $(P<0.001)$ were lowest for HPA $(77.7 \%$ and $220 \mathrm{~g} / \mathrm{kg}$, respectively), highest for LPA (78.6\% and 242 $\mathrm{g} / \mathrm{kg}$, respectively) and intermediate for MPA (78.0\% and $230 \mathrm{~g} / \mathrm{kg}$, respectively). The greatest differences in both OMd and CP occurred during wk 4 to 8 , corresponding to the greatest differential in HM between PA treatments (Figure 4). Despite the differences in CP and $\mathrm{OMd}$, there was no significant difference in ADF, NDF, or Unité Fourragère Lait values between LPA, MPA, and HPA (253, $430 \mathrm{~g} / \mathrm{kg}$ and 0.96, respectively).

\section{DMI, Milk Production Performance, BW, and BCS During Autumn}

The effect of FS and PA treatment on daily DMI, milk production, BW, and BCS is illustrated in Table 4. There was no significant interaction between FS and PA for any of the DMI and milk production and composition variables analyzed. Year had a significant effect on all milk production parameters except for protein composition. Farm system had a significant effect on DMI and all daily milk yield parameters but not on milk composition. The MI system, by virtue of a lower SR and increased DHA, achieved a higher daily PDMI $(+1.8 \mathrm{~kg}$ of $\mathrm{DM} / \mathrm{cow})$ compared with $\mathrm{HI}$ (12.9 $\mathrm{kg}$ of $\mathrm{DM} / \mathrm{cow})$. Based on the additional daily concentrate supplementation, $\mathrm{HI}$ achieved a greater $(P$ $<0.05)$ daily milk $(+0.50 \mathrm{~kg})$, fat $(+28.5 \mathrm{~g})$, protein $(+6.7 \mathrm{~g})$, lactose $(+36.3 \mathrm{~g}), \mathrm{SCM}(+0.7 \mathrm{~kg})$, and MS $(+0.05 \mathrm{~kg})$ yield compared with MI $(15.5,850.0,639.6$, $699.2,18.1$, and $1.61 \mathrm{~kg}$, respectively). There was no significant effect of FS on BW or BCS.

Furthermore, there was no effect of PA treatment on daily PDMI (13.8 kg of DM/cow), concentrate (2.7 $\mathrm{kg}$ of $\mathrm{DM} / \mathrm{cow})$, or total DMI (16.5 $\mathrm{kg}$ of $\mathrm{DM} / \mathrm{cow})$ during autumn. There was also no significant effect of PA on autumn daily milk (15.7 kg), fat (864.2 g), protein $(648.3 \mathrm{~g})$, lactose $(717.3 \mathrm{~g}), \mathrm{SCM}(18.4 \mathrm{~kg})$, or MS yield $(1.64 \mathrm{~kg})$. Milk fat content was greater for MPA $(58.9 \mathrm{~g} / \mathrm{kg})$ compared with both HPA and LPA (57.1 and $57.4 \mathrm{~g} / \mathrm{kg}$, respectively), whereas PA had no effect on milk protein or lactose content (43.0 and 46.1 $\mathrm{g} / \mathrm{kg}$, respectively). Pasture availability treatment had a significant $(P<0.05)$ effect on BW as MPA achieved a greater average $\mathrm{BW}(+12 \mathrm{~kg})$ compared with LPA $(513 \mathrm{~kg})$ during autumn, whereas HPA was intermediate $(518 \mathrm{~kg})$. There was no significant effect of PA on average BCS during autumn (2.89 units).

\section{Milk Production and Supplementation per Hectare During Autumn}

The effect of year on grazing days, MS production, and supplementary concentrate requirements per hectare is displayed in Figure 5. Although it had no significant effect on grazing days per hectare, year had a significant effect on both MS production and supplementary feed requirements. Total MS production per hectare was greatest in yr $2(358 \mathrm{~kg})$, corresponding to the period of greatest concentrate supplementation, least in yr $1(236 \mathrm{~kg})$ and intermediate in yr $3(334 \mathrm{~kg})$. On average, $827 \mathrm{~kg}$ of DM of concentrate and $131 \mathrm{~kg}$ of DM of silage per hectare were fed over the 3-yr period. Due to low rainfall and depressed pasture growth during summer and autumn in yr 2, the highest levels of supplementation were required with $1,406 \mathrm{~kg}$ of DM of concentrate per hectare fed. In contrast, the lowest levels of concentrate supplementation (491 kg of DM/ ha) and no silage were required in yr 1 when pasture growth was above average, resulting in the lowest MS production period.

While there was no significant effect of FS on silage supplementation per hectare, concentrate supplementation per hectare was greater $(P<0.001)$ for HI com- 
a)

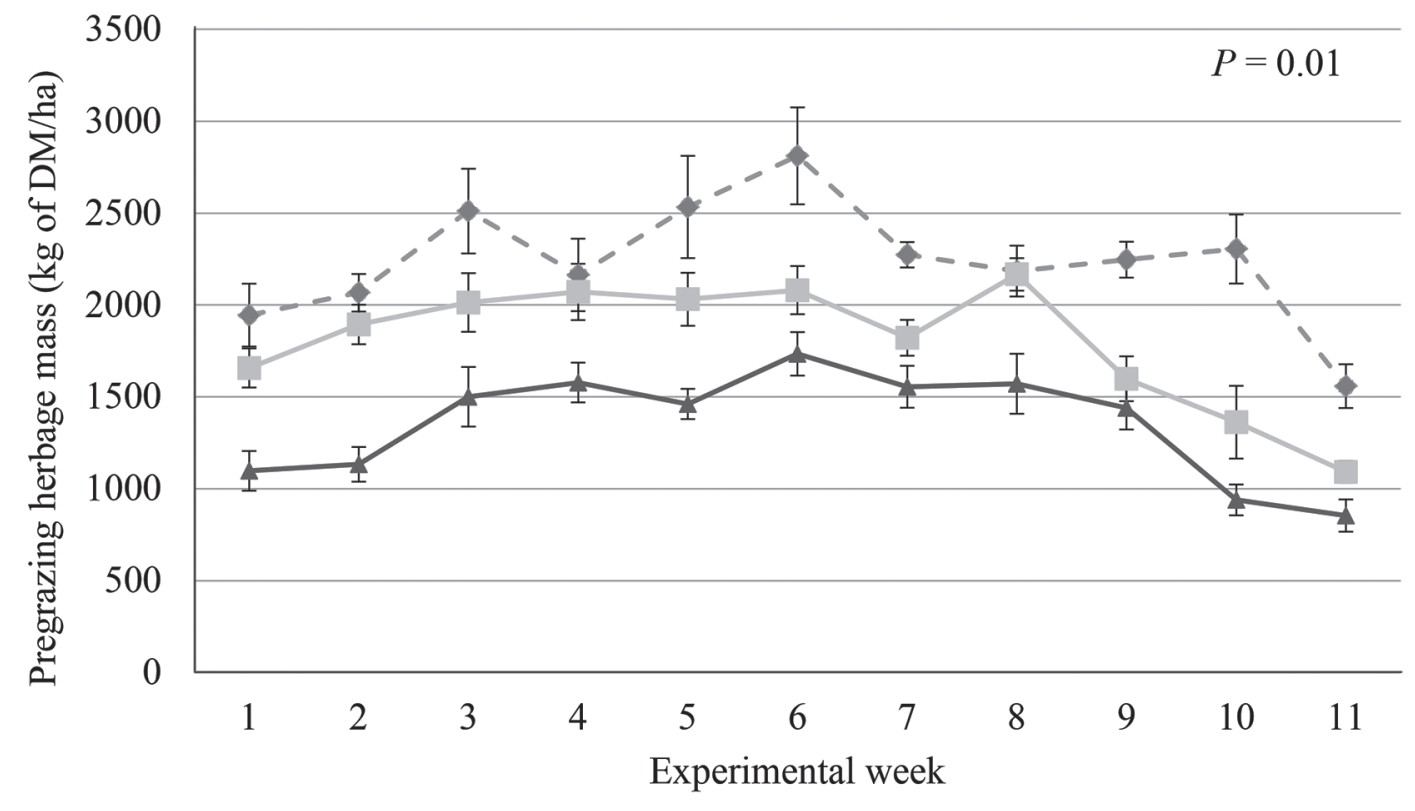

b)

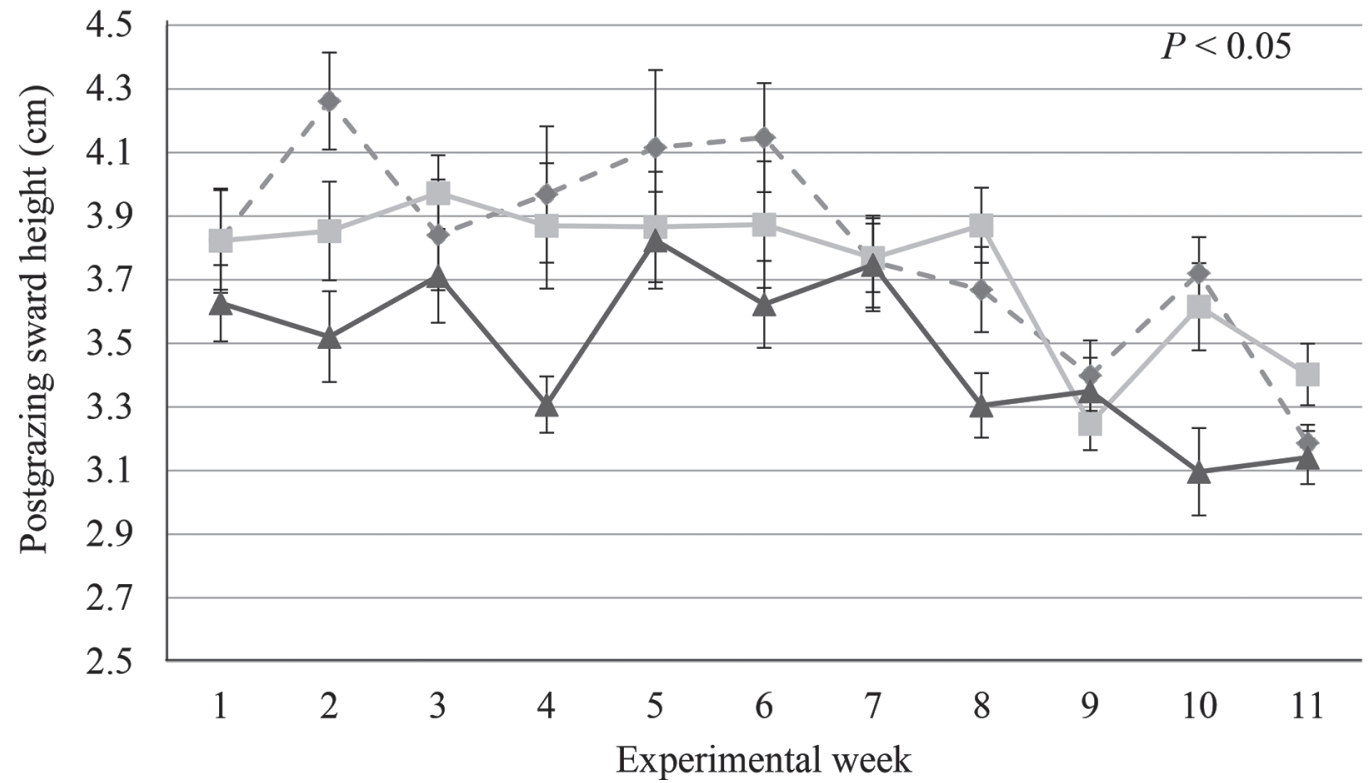

Figure 3. Effect of pasture availability treatment $( \pm \mathrm{SE})$ on weekly average (a) pregrazing herbage mass and (b) postgrazing sward height during the 11-wk study period. LPA = low pasture availability $(\mathbf{\Lambda})$; MPA = medium pasture availability $(\mathbf{\square}) ; \mathrm{HPA}=$ high pasture availability, $(\diamond)$.

pared with MI (1,089 vs. $566 \mathrm{~kg}$ of DM; Figure 5). The HI, by virtue of a higher SR, also achieved a greater $(P$ $<0.001)$ number of grazing days per hectare $(246 \mathrm{~d} /$ ha) compared with MI (211 d/ha). In contrast to MI, HI consistently achieved greater $(P<0.001)$ milk, fat protein, lactose, and MS yield per hectare $(+723,+31$, $+28,+30$, and $+52 \mathrm{~kg} / \mathrm{ha}$; Table 2 ).

Pasture availability treatment had no significant effect on concentrate and silage supplementation per hectare. There was also no significant effect of PA on 
Table 2. The effect of farm system (FS) and pasture availability (PA) on cumulative pasture production, supplementary feed and milk production per hectare during autumn

\begin{tabular}{|c|c|c|c|c|c|c|c|c|c|c|}
\hline \multirow{2}{*}{ Item } & \multicolumn{6}{|c|}{ Treatment $^{1}$} & \multirow{2}{*}{$\mathrm{SE}$} & \multirow{2}{*}{\multicolumn{3}{|c|}{$P$-value }} \\
\hline & \multicolumn{3}{|c|}{ MI } & \multicolumn{3}{|c|}{$\mathrm{HI}$} & & & & \\
\hline \multicolumn{11}{|l|}{$\begin{array}{l}\text { Cumulative pasture production } \\
\text { (kg of DM/ha) }\end{array}$} \\
\hline Grazed pasture & 3,111 & 3,212 & 3,227 & 2,998 & 3,156 & 3,187 & 120.0 & $<0.001$ & 0.48 & 0.40 \\
\hline Grazing days (d/ha) & 222 & 213 & 210 & 253 & 250 & 245 & 10.8 & 0.004 & $<0.001$ & 0.65 \\
\hline Number of grazing rotations & 2.1 & 1.6 & 1.4 & 2.1 & 1.6 & 1.4 & 0.08 & 0.13 & 0.41 & $<0.001$ \\
\hline \multicolumn{11}{|c|}{ Supplementary feed ( $\mathrm{kg}$ of DM/ha) } \\
\hline Concentrate & 652 & 648 & 583 & 1,223 & 1,255 & 1,157 & 60.2 & $<0.001$ & $<0.001$ & 0.36 \\
\hline Silage & 107 & 124 & 123 & 129 & 149 & 157 & 37.6 & $<0.001$ & 0.38 & 0.82 \\
\hline Total & 761 & 776 & 710 & 1,350 & 1,404 & 1,314 & 79.7 & $<0.001$ & $<0.001$ & 0.62 \\
\hline \multicolumn{11}{|c|}{ Milk production per hectare $(\mathrm{kg} / \mathrm{ha})$} \\
\hline
\end{tabular}

${ }^{1} \mathrm{MI}=$ medium intensity; $\mathrm{HI}=$ high intensity; LPA = low pasture availability; MPA = medium pasture availability; HPA = high pasture availability.

the number of grazing days per hectare achieved (233 d/ha) during autumn. Moreover, there was no difference in milk, fat, protein, lactose, and MS yield per hectare between PA treatment groups $(3,758,154,162$, 157, and $309 \mathrm{~kg} /$ ha, respectively).

\section{DISCUSSION}

Although grazing systems are widely recognized for the positive effects on both the natural environment and the welfare of animals (Plantureux et al., 2016; European Union, 2019; Mee and Boyle, 2020), the recent intensification of such systems and reduced reliance on extended grazing due to widespread availability of affordable feed supplements is now among the main concerns for the European Union dairy sector (Nalon and Stevenson, 2019). The current study was conceived to evaluate the capability for altered grazing management practices within 2 farm systems during autumn to increase the average pasture cover on farm and to maintain a high reliance on grazed pasture within an extended grazing season for intensive pasture-based systems. There is a significant focus in grazing systems on maximizing animal intake and the utilization and quality of pasture throughout the main grazing season (Kennedy et al., 2006). Previous studies have indicated that for each $1 \mathrm{t}$ of $\mathrm{DM} /$ ha of additional pasture utilization in grazing dairy systems, annual net farm profit is increased [by €173/ha in Ireland (Hanrahan et al., 2018) and by NZ $\$ 297 /$ ha in New Zealand (Neal and

Table 3. The effect of farm system (FS) and pasture availability (PA) and on sward quality during autumn

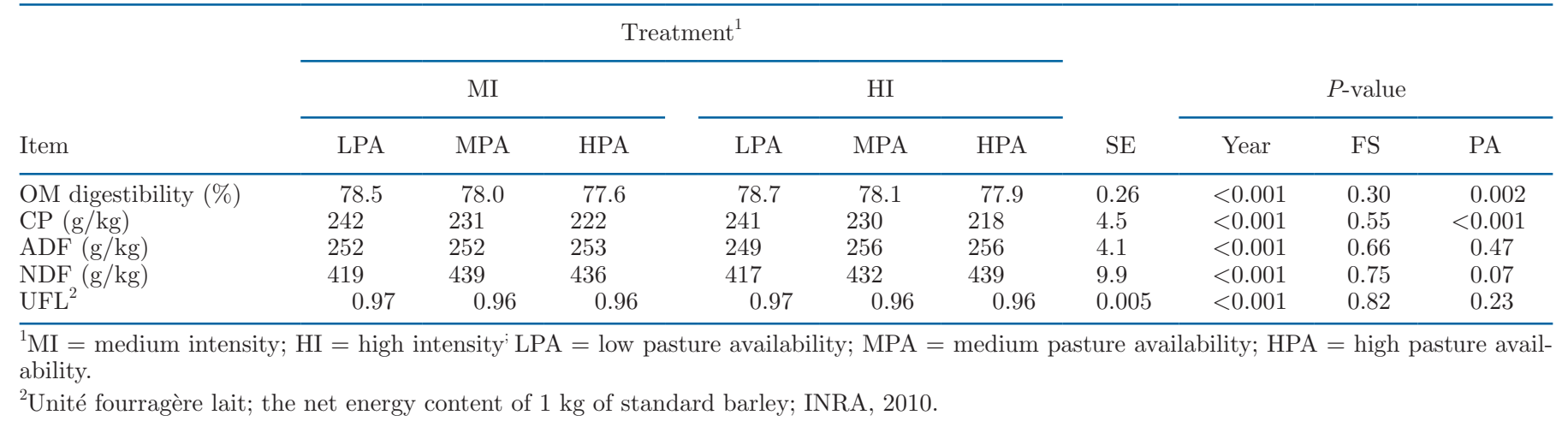


A

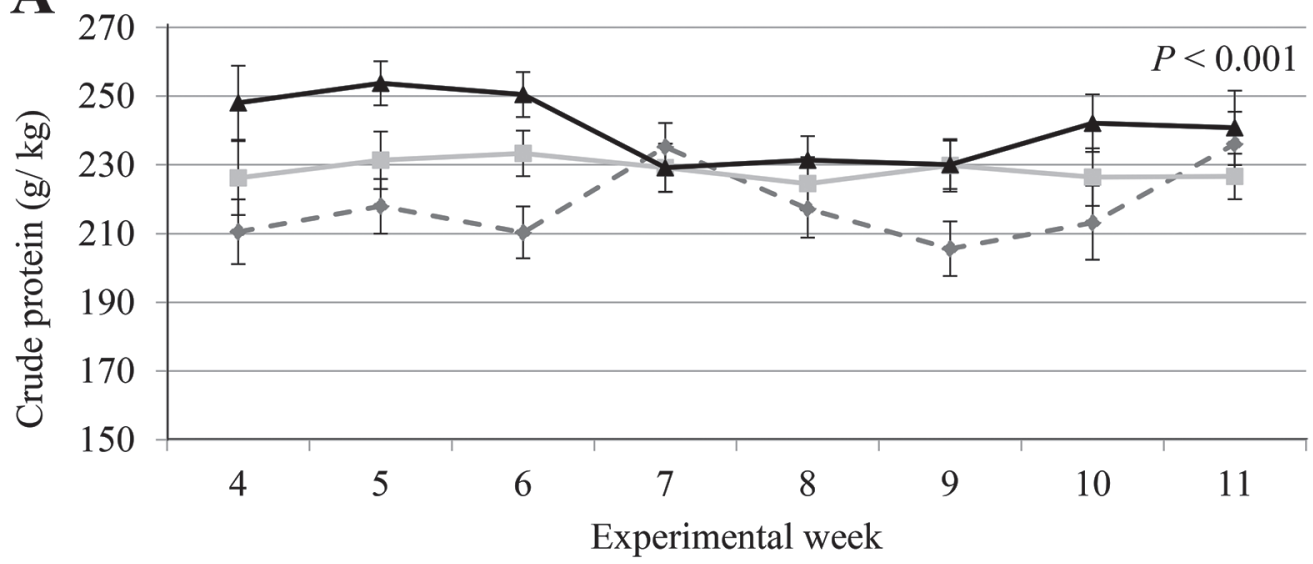

B

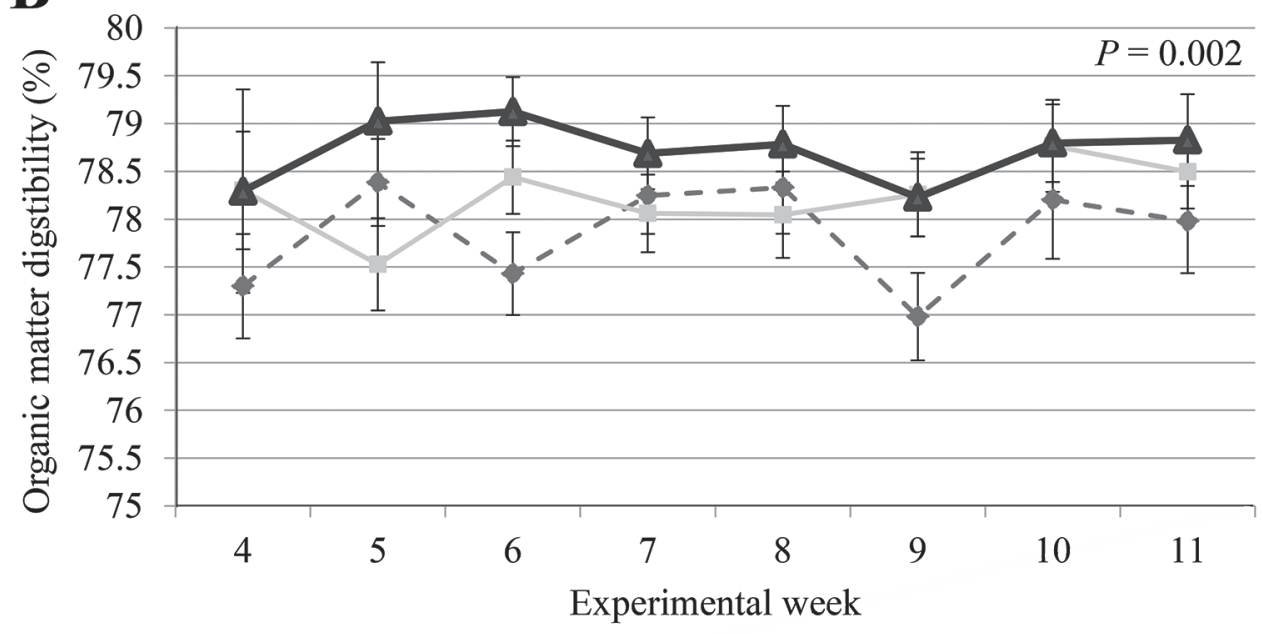

$\mathbf{C}$

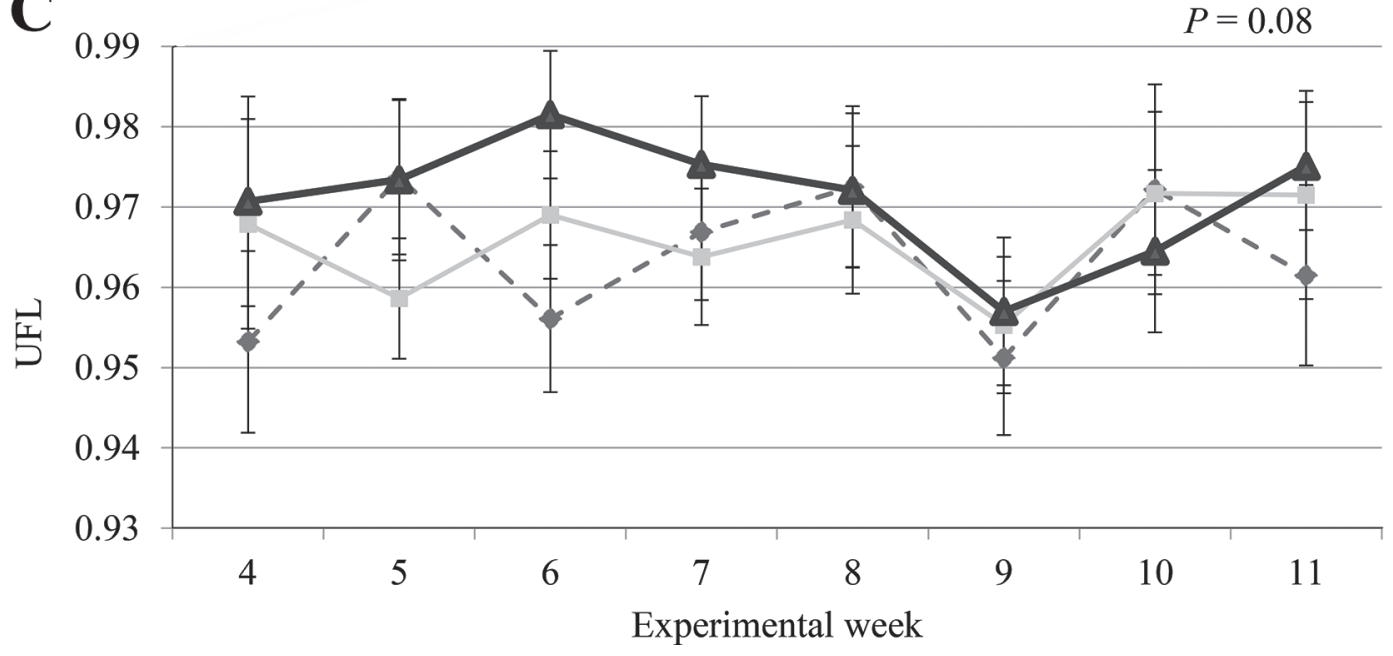

Figure 4. Effect of pasture availability treatment $( \pm \mathrm{SE})$ on weekly average sward (a) organic matter digestibility, (b) CP content, and (c) UFL (unité fourragère lait; the net energy content of $1 \mathrm{~kg}$ of standard barley; INRA, 2010) during the last grazing rotation. LPA $=$ low pasture availability $(\mathbf{\Lambda}) ; \mathrm{MPA}=$ medium pasture availability $(\mathbf{\square})$; HPA = high pasture availability, $(\diamond)$. 
Table 4. The effect of farm system (FS) and pasture availability (PA) and on animal intake, daily milk production, BW, and BCS during autumn

\begin{tabular}{|c|c|c|c|c|c|c|c|c|c|c|}
\hline \multirow[b]{3}{*}{ Item } & \multicolumn{6}{|c|}{ Treatment $^{1}$} & \multirow[b]{3}{*}{ SE } & \multirow{2}{*}{\multicolumn{3}{|c|}{$P$-value }} \\
\hline & \multicolumn{3}{|c|}{ MI } & \multicolumn{3}{|c|}{$\mathrm{HI}$} & & & & \\
\hline & LPA & MPA & HPA & LPA & MPA & HPA & & Year & FS & $\mathrm{PA}$ \\
\hline \multicolumn{11}{|l|}{$\begin{array}{l}\text { Daily DMI (kg of } \\
\text { DM/cow) }\end{array}$} \\
\hline Pasture (PDMI) & 14.6 & 14.6 & 14.9 & 13.3 & 12.7 & 12.8 & 0.29 & $<0.001$ & $<0.001$ & 0.41 \\
\hline Concentrate (CDMI) & 1.7 & 1.9 & 1.7 & 3.5 & 3.5 & 3.5 & 0.03 & 0.55 & $<0.001$ & 0.20 \\
\hline Total (TDMI) & 16.4 & 16.5 & 16.7 & 16.8 & 16.1 & 16.3 & 0.29 & $<0.001$ & 0.59 & 0.53 \\
\hline \multicolumn{11}{|l|}{ Daily milk production } \\
\hline Milk yield (kg/cow) & 15.6 & 15.3 & 15.5 & 16.3 & 15.9 & 15.7 & 0.28 & $<0.001$ & 0.03 & 0.33 \\
\hline Fat yield $(\mathrm{g} / \mathrm{cow})$ & 854.7 & 864.2 & 831.2 & 885.3 & 892.7 & 857.5 & 0.01 & $<0.001$ & 0.01 & 0.04 \\
\hline Protein yield ( $\mathrm{g} / \mathrm{cow})$ & 644.2 & 637.9 & 636.6 & 664.4 & 663.4 & 643.3 & 0.01 & $<0.001$ & 0.04 & 0.35 \\
\hline Lactose yield (g/cow) & 709.8 & 683.3 & 704.5 & 764.2 & 725.1 & 717 & 0.02 & $<0.001$ & 0.02 & 0.19 \\
\hline $\mathrm{SCM}^{2}$ yield $(\mathrm{kg} / \mathrm{cow})$ & 18.4 & 18.0 & 17.8 & 19.2 & 18.8 & 18.3 & 0.04 & $<0.001$ & 0.01 & 0.13 \\
\hline $\begin{array}{l}\text { Milk solids yield } \\
(\mathrm{kg} / \mathrm{cow})\end{array}$ & 1.64 & 1.61 & 1.59 & 1.68 & 1.67 & 1.63 & 0.09 & $<0.001$ & 0.03 & 0.15 \\
\hline \multicolumn{11}{|l|}{ Milk composition $(\mathrm{g} / \mathrm{kg})$} \\
\hline Fat & 57.6 & 58.7 & 56.7 & 57.2 & 59.0 & 57.5 & 0.06 & $<0.001$ & 0.61 & 0.006 \\
\hline Protein & 42.9 & 43.2 & 43.1 & 42.7 & 43.4 & 42.7 & 0.03 & 0.27 & 0.53 & 0.16 \\
\hline Lactose & 46.0 & 45.5 & 46.0 & 46.9 & 46.1 & 46.3 & 0.06 & $<0.001$ & 0.22 & 0.52 \\
\hline BW (kg) & 516 & 522 & 515 & 510 & 529 & 522 & 5.1 & $<0.001$ & 0.52 & 0.04 \\
\hline $\mathrm{BCS}^{3}$ & 2.87 & 2.88 & 2.88 & 2.88 & 2.91 & 2.89 & 0.024 & $<0.001$ & 0.20 & 0.48 \\
\hline
\end{tabular}

Roche, 2020)]. The novel objective of this study was to investigate the effects of alternative autumn pasture management strategies that increase overall pasture availability on farm without increasing the use of supplementary feed or shortening the grazing season and therefore maintaining a predominantly low-cost pasture-based system.

Similar to previous findings (Roche et al., 2009; Patton et al., 2016; Claffey et al., 2020), meteorological conditions can have a significant effect on pasture production and quality, resulting in significant year effects within multiyear grazing studies. In the current study, a nearly $50 \%$ reduction in average rainfall during summer in yr 2 resulted in significantly increased concentrate supplementation requirements to mitigate the decline in pasture growth and availability during autumn. Due to the lower-than-normal pasture growth rates in yr 2 , grazing rotation lengths were reduced as a result of lower pregrazing HM compared with yr 1 and 3, and target peak pasture cover for MPA and HPA could not be achieved in early October. This also entailed a shorter residency time in each paddock and increased concentrate supplementation. Equally, an exceptionally wet autumn in yr 3 (when rainfall levels were $144 \%$ of the 10-year average) reduced pasture availability and consequently led to a period of additional concentrate and silage supplementation. On that basis, and similar to the findings of both Patton et al. (2016) and Claffey et al. (2020), additional quantities of concentrate and silage are required within intensive grazing systems as a contingency for unexpected climatic conditions.

Overall grazable land availability is a major limitation for grazing dairy systems and thus, maximizing milk output per hectare is important. Stocking rate, and therefore grazing days per hectare, are widely acknowledged as the main drivers of milk output and pasture utilization per hectare (Macdonald et al., 2008; McCarthy et al., 2016; Coffey et al., 2018). Previous studies have shown that a lower PGSH and a higher SR negatively affect individual cow performance due to lower DHA (McEvoy et al., 2008; McCarthy et al., 2014). The modest increase in individual cow performance of the HI farm system in this study is consistent with other similar studies in which the lower PGSH achieved with an increase in SR has been effectively combined with additional concentrate supplementation (Coleman et al., 2010; Patton et al., 2016). Indeed, some studies, in which incorporating concentrates in the late lactation diet in higher SR systems resulted in an increase in total DMI, have reported significantly increased milk and MS production per cow (O'Brien et al., 1996; McKay, et al., 2019). We concluded that the 

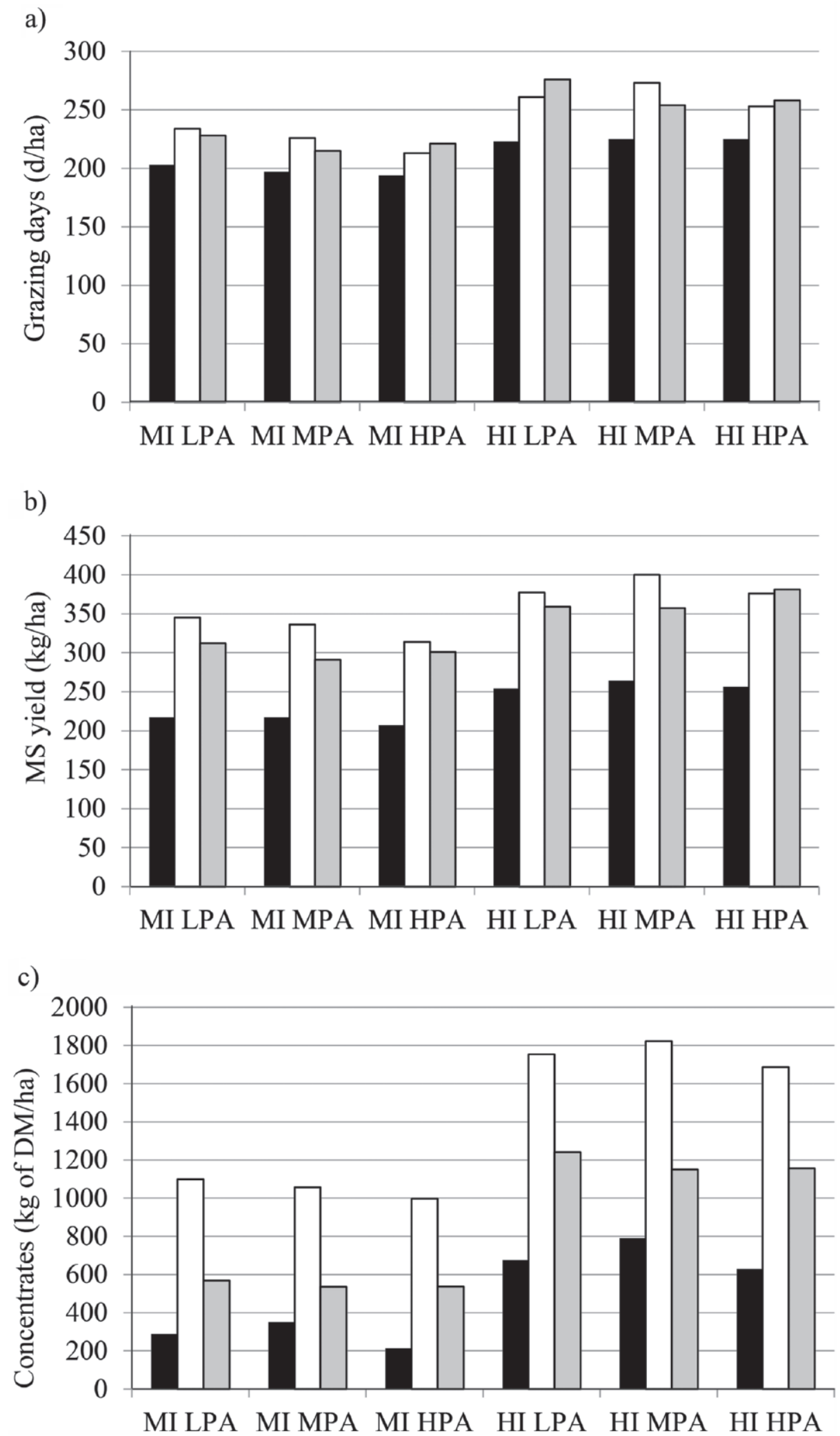

Figure 5. The effect of year on cumulative per hectare (a) grazing days, (b) milk solid (MS) yield, and (c) concentrate supplementation requirements for each farm system and pasture availability treatment during yr 1 (black), yr 2 (white) and yr 3 (gray). MI = medium intensity farm system; HI = high intensity farm system; LPA = low pasture availability; HPA = high pasture availability; and MPA = medium pasture availability. 
high levels of pasture utilization (characterized by the lower PGSH), coupled with the lack of a difference in total DMI between FS in this study is indicative of the efficient use of additional supplement within HI similar to previous studies (Coleman et al., 2010; Patton et al., 2016).

Although both Lee et al. (2008) and Peyraud and Delagarde (2013) observed a reduction in sward quality, pasture production, and tiller density with continuously laxly grazed swards where a severe difference in PGSH of $2 \mathrm{~cm}$ was imposed, the difference of $0.3 \mathrm{~cm}$ in PGSH between FS treatments from this study was comparably small and therefore did not deleteriously affect pasture quality. Likewise, the increase in PA and associated increase in pregrazing HM within MPA and HPA treatments had little or no detrimental effect on pasture utilization and DMI and is similar to both Lawrence et al. (2017) and Claffey et al. (2020). Although it is widely accepted that increasing pregrazing HM during autumn results in increased leaf senescence (Holmes et al., 1992; Fulkerson and Donaghy, 2001), the effects on autumn sward nutritive value are conflicted (Parsons et al., 1988; Hennessy et al., 2006; Beecher et al., 2015). In this study, where pastures were consistently grazed to a PGSH of 3.5 to $4.0 \mathrm{~cm}$ during autumn, extending rotation length by up to $13 \mathrm{~d}$ (LPA vs. HPA) and increasing pregrazing HM had little effect on pasture utilization and sward nutritive value. Similarly, both Wims et al. (2010) and Beecher et al. (2015) observed no significant sward nutritive quality decline with increased pregrazing HM during late summer and autumn and reported no effect on animal performance. At a practical level, the absence of significant FS and PA interaction effects on cumulative pasture production and quality within the range of treatments reported here, suggests that autumn pasture productivity and quality is relatively insensitive to changes in pregrazing HM and grazing intensity.

Consistent with the negligible effect on pasture performance, PA treatment had no significant effect on animal intake and performance during autumn. The overall levels of DMI and milk production achieved were similar to previous studies (Coffey et al., 2016; Claffey et al., 2020) and indicative of the high productivity potential of autumn pasture. Similarly, numerous previous albeit short-term studies have reported the capability of high HM swards to support increased milk production per hectare (Holmes et al., 1992; Kennedy et al., 2006). More recently, Claffey et al. (2020) also observed no significant effect of early and delayed autumn closing strategies on milk and MS yield during autumn, whereas the resulting increase in pasture availability in spring in that study resulted in increased animal performance.

\section{CONCLUSIONS}

The results of the present study confirmed the hypotheses and indicate that increasing SR in combination with additional feed supplementation in intensive grazing systems can maintain a high dependence on high-quality grazed pasture, can increase pasture utilization, and can achieve a modest increase in animal performance in late lactation. Furthermore, this study also indicates that increasing PA by extending autumn grazing rotation length can be an effective strategy to achieve an extended grazing season into late autumn while also provisioning additional pasture for early spring turnout. Indeed, the overall similarity in cumulative pasture production, quality, utilization, and animal performance between PA treatments reported here indicates that autumn pasture productivity and quality is relatively insensitive to changes in pregrazing HM and grazing intensity.

\section{ACKNOWLEDGMENTS}

The authors thank the staff of Curtin's Research Farm (Animal \& Grassland Research and Innovation Centre, Teagasc Moorepark, Ireland) for their cooperation, care, and management of the experimental cows. The authors acknowledge the financial support of the Dairy Research Levy and the Teagasc Walsh Scholarship scheme. The project is a collaborative initiative supported by both Teagasc (Ireland) and INRA (France). The authors have not stated any conflicts of interest.

\section{REFERENCES}

Beecher, M., D. Hennessy, T. Boland, M. McEvoy, M. O'Donovan, and E. Lewis. 2015. The variation in morphology of perennial ryegrass cultivars throughout the grazing season and effects on organic matter digestibility. Grass Forage Sci. 70:19-29. https://doi.org/ 10.1111/gfs.12081.

Beecher, M., D. Hennessy, T. M. Boland, M. O'Donovan, and E. Lewis. 2013. Comparing drying protocols for perennial ryegrass samples in preparation for chemical analysis. Paper presented at the Revitalising Grasslands to Sustain our Communities: Proceedings, 22nd Int. Grassl. Congr., Sydney, Australia.

Carton, O. T., A. J. Brereton, W. F. O'Keeffe, and G. P. Keane. 1988. Effects of autumn closing date and grazing severity in a rotationally grazed sward during winter and spring: 1. Dry matter production. Ir. J. Agric. Res. 27:141-150.

Claffey, A., L. Delaby, T. Boland, and M. Egan. 2020. Implications of adapting autumn grazing management on spring herbage production-the effect on late lactation milk production and the subsequent response in early lactation animal performance. Livest. Sci. 231:103870. https://doi.org/10.1016/j.livsci.2019.103870.

Clay, N., T. Garnett, and J. Lorimer. 2020. Dairy intensification: Drivers, impacts and alternatives. Ambio 49:35-48. https://doi.org/10 .1007/s13280-019-01177-y.

Coffey, E. L., L. Delaby, C. Fleming, K. M. Pierce, and B. Horan. 2018. Multi-year evaluation of stocking rate and animal genotype on milk production per hectare within intensive pasture-based pro- 
duction systems. J. Dairy Sci. 101:2448-2462. https://doi.org/10 $.3168 /$ jds.2017-13632.

Coffey, E., B. Horan, R. Evans, and D. P. Berry. 2016. Milk production and fertility performance of Holstein, Friesian, and Jersey purebred cows and their respective crosses in seasonal-calving commercial farms. J. Dairy Sci. 99:5681-5689. https://doi.org/10 $.3168 /$ jds.2015-10530.

Coleman, J., D. P. Berry, K. M. Pierce, A. Brennan, and B. Horan. 2010. Dry matter intake and feed efficiency profiles of 3 genotypes of Holstein-Friesian within pasture-based systems of milk production. J. Dairy Sci. 93:4318-4331. https://doi.org/10.3168/jds.2009 -2686 .

Delaby, L., and B. Horan. 2017. Improved efficiency in temperate grass based dairy systems. 54. Pages 133-145 in Proc Annu. Mtg. Brazilian Society of Animal Science, Foz do Iguaçu, Brazil.

Delaby, L., and J. L. Peyraud. 1998. Effet d'une réduction simultanée de la fertilisation azotée et du chargement sur les performances des vaches laitières et la valorisation du pâturage. Ann. Zootech. 47:17-39. https://doi.org/10.1051/animres:19980102.

Dillon, P., and G. Stakelum. 1989. Herbage and dosed alkanes as a grass measurement technique for dairy cows. Isr. J. Agric. Res. $28: 104$.

Dillon, P. G. 1993. The use of n-alkanes as markers to determine herbage intake, botanical composition of available or consumed herbage and in studies of digesta kinetics with dairy cows. PhD thesis. National University of Ireland, Dublin, Ireland.

European Union. 2019. LIFE helps farming and forestry adapt to climate change. https://ec.europa.eu/easme/sites/easme-site/files/ life_cca-forest_agri-.pdf.

Edmonson, A., I. Lean, L. Weaver, T. Farver, and G. Webster. 1989. A body condition scoring chart for Holstein dairy cows. J. Dairy Sci. 72:68-78. https://doi.org/10.3168/jds.S0022-0302(89)79081-0.

Fulkerson, W., and D. Donaghy. 2001. Plant-soluble carbohydrate reserves and senescence-key criteria for developing an effective grazing management system for ryegrass-based pastures: A review. Aust. J. Exp. Agric. 41:261-275. https://doi.org/10.1071/ EA00062.

Garry, B., M. O'Donovan, M. Beecher, L. Delaby, C. Fleming, R. Baumont, and E. Lewis. 2018. Predicting in vivo digestibility of perennial ryegrass using the neutral detergent cellulase method: Updating the equation. Sustainable meat and milk production from grasslands. In: Proceedings of the 27th General Meeting of the European Grassland Federation, Cork, Ireland.

Godfray, H. C. J., and T. Garnett. 2014. Food security and sustainable intensification. Philos. Trans. R. Soc. Lond. B Biol. Sci. 369:20120273. https://doi.org/10.1098/rstb.2012.0273.

Hanrahan, L., A. Geoghegan, M. O'Donovan, V. Griffith, E. Ruelle, M. Wallace, and L. Shalloo. 2017. PastureBase Ireland: A grassland decision support system and national database. Comput. Electron. Agric. 136:193-201. https://doi.org/10.1016/j.compag 2017.01.029

Hanrahan, L., N. McHugh, T. Hennessy, B. Moran, R. Kearney, M. Wallace, and L. Shalloo. 2018. Factors associated with profitability in pasture-based systems of milk production. J. Dairy Sci. 101:5474-5485. https://doi.org/10.3168/jds.2017-13223.

Hennessy, D., M. O'Donovan, P. French, and A. Laidlaw. 2006. Effects of date of autumn closing and timing of winter grazing on herbage production in winter and spring. Grass Forage Sci. 61:363-374. https://doi.org/10.1111/j.1365-2494.2006.00543.x.

Hoden, A., J. Peyraud, A. Muller, L. Delaby, P. Faverdin, J. Peccatte, and M. Fargetton. 1991. Simplified rotational grazing management of dairy cows: effects of rates of stocking and concentrate. J. Agric. Sci. 116:417-428. https://doi.org/10.1017/S0021859600078230.

Holmes, C. W., C. J. Hoogendoorn, M. P. Ryan, and A. C. P. Chu. 1992. Some effects of herbage composition, as influenced by previous grazing management, on milk production by cows grazing on ryegrass/white clover pastures. 1. Milk production in early spring: effects of different regrowth intervals during the preceding winter period. Grass Forage Sci. 47:309-315. https://doi.org/10.1111/j 1365-2494.1992.tb02276.x.
INRA. 2010. Alimentation des bovins, ovins et caprins. Tables Inra 2007, mise à jour 2010. QUAE Editions.

Kennedy, E., M. McEvoy, J. Murphy, and M. O'Donovan. 2009. Effect of restricted access time to pasture on dairy cow milk production, grazing behavior, and dry matter intake. J. Dairy Sci. 92:168-176. https://doi.org/10.3168/jds.2008-1091.

Kennedy, E., M. O'Donovan, J. Murphy, F. O'Mara, and L. Delaby. 2006. The effect of initial spring grazing date and subsequent stocking rate on the grazing management, grass dry matter intake and milk production of dairy cows in summer. Grass Forage Sci 61:375-384. https://doi.org/10.1111/j.1365-2494.2006.00544.x.

Kennedy, E., M. O'Donovan, J. P. Murphy, L. Delaby, and F. O'Mara. 2005. Effects of grass pasture and concentrate-based feeding systems for spring-calving dairy cows in early spring on performance during lactation. Grass Forage Sci. 60:310-318. https://doi.org/10 .1111/j.1365-2494.2005.00481.x.

Läpple, D., T. Hennessy, and M. O'Donovan. 2012. Extended grazing: A detailed analysis of Irish dairy farms. J. Dairy Sci. 95:188-195. https://doi.org/10.3168/jds.2011-4512.

Lawrence, D. C., M. O'Donovan, T. Boland, and E. Kennedy. 2017. Effects of autumn and spring defoliation management on the drymatter yield and herbage quality of perennial ryegrass swards throughout the year. Grass Forage Sci. 72:38-49. https://doi.org/ $10.1111 /$ gfs.12226.

Lee, J. M., D. J. Donaghy, and J. R. Roche. 2008. Effect of defoliation severity on regrowth and nutritive value of perennial ryegrass dominant swards. Agron. J. 100:308-314. https://doi.org/10.2134/ agronj2007.0099.

Ma, W., A. Renwick, and K. Bicknell. 2018. Higher intensity, higher profit? Empirical evidence from dairy farming in New Zealand. J. Agric. Econ. 69:739-755. https://doi.org/10.1111/1477-9552 .12261.

Macdonald, K. A., J. Penno, J. Lancaster, A. Bryant, J. Kidd, and J. Roche. 2017. Production and economic responses to intensification of pasture-based dairy production systems. J. Dairy Sci. 100:66026619. https://doi.org/10.3168/jds.2016-12497.

Macdonald, K. A., J. Penno, J. Lancaster, and J. Roche. 2008. Effect of stocking rate on pasture production, milk production, and reproduction of dairy cows in pasture-based systems. J. Dairy Sci. 91:2151-2163. https://doi.org/10.3168/jds.2007-0630.

Mayes, R., C. Lamb, and P. M. Colgrove. 1986. The use of dosed and herbage n-alkanes as markers for the determination of herbage intake. J. Agric. Sci. 107:161-170. https://doi.org/10.1017/ S0021859600066910.

McCarthy, B., K. M. Pierce, L. Delaby, A. Brennan, and B. Horan. 2012. The effect of stocking rate and calving date on reproductive performance, body state, and metabolic and health parameters of Holstein-Friesian dairy cows. J. Dairy Sci. 95:1337-1348. https:// doi.org/10.3168/jds.2011-4783.

McCarthy, B., L. Delaby, K. M. Pierce, A. Brennan, and B. Horan. 2013. The effect of stocking rate and calving date on milk production of Holstein-Friesian dairy cows. Livest. Sci. 153:123-134. https://doi.org/10.1016/j.livsci.2013.01.013.

McCarthy, B., L. Delaby, K. M. Pierce, J. McCarthy, C. Fleming, A. Brennan, and B. Horan. 2016. The multi-year cumulative effects of alternative stocking rate and grazing management practices on pasture productivity and utilization efficiency. J. Dairy Sci. 99:3784-3797. https://doi.org/10.3168/jds.2015-9763.

McCarthy, J., B. McCarthy, B. Horan, K. M. Pierce, N. Galvin, A. Brennan, and L. Delaby. 2014. Effect of stocking rate and calving date on dry matter intake, milk production, body weight, and body condition score in spring-calving, grass-fed dairy cows. J. Dairy Sci. 97:1693-1706. https://doi.org/10.3168/jds.2013-7458.

McEvoy, M., E. Kennedy, J. Murphy, T. Boland, L. Delaby, and M. O'Donovan. 2008. The effect of herbage allowance and concentrate supplementation on milk production performance and dry matter intake of spring-calving dairy cows in early lactation. J. Dairy Sci. 91:1258-1269. https://doi.org/10.3168/jds.2007-0710.

McKay, Z. C., B. Lynch, F. J. Mulligan, G. Rajauria, C. Miller, and K. M. Pierce. 2019. The effect of concentrate supplementation type 
on milk production, dry matter intake, rumen fermentation, and nitrogen excretion in late-lactation, spring-calving grazing dairy cows. J. Dairy Sci. 102:5042-5053. https://doi.org/10.3168/jds .2018-15796.

Mee, J. F., and L. A. Boyle. 2020. Assessing whether dairy cow welfare is "better" in pasture-based than in confinement-based management systems. N. Z. Vet. J. 68:168-177. https://doi.org/10.1080/ 00480169.2020 .1721034$.

Morgan, D. J., G. Stakelum, and J. O'Dwyer. 1989. Modified neutral detergent cellulose digestibility procedure for use with the 'Fibertec' system. Isr. J. Agric. Res. 28:91-92.

Mottet, A., C. de Haan, A. Falcucci, G. Tempio, C. Opio, and P. Gerber. 2017. Livestock: On our plates or eating at our table? A new analysis of the feed/food debate. Glob. Food Secur. 14:1-8. https: //doi.org/10.1016/j.gfs.2017.01.001.

Nalon, E., and P. Stevenson. 2019. Protection of dairy cattle in the EU: State of play and directions for policymaking from a legal and animal advocacy perspective. Animals (Basel) 9:1066. https://doi . org/10.3390/ani9121066.

Neal, M., and J. R. Roche. 2020. Profitable and resilient pasture-based dairy farm businesses in New Zealand. Anim. Prod. (Purwokerto) 60:169-174. https://doi.org/10.1071/AN18572.

O'Brien, B., S. Crosse, and P. Dillon. 1996. Effects of offering a concentrate or silage supplement to grazing dairy cows in late lactation on animal performance and on milk processability. Ir. J. Agric. Food Res. 35:113-125.

O'Donovan, M., P. Dillon, M. Rath, and G. Stakelum. 2002. A comparison of four methods of herbage mass estimation. Ir. J. Agric. Food Res. 41:17-27.

Parsons, A., I. Johnson, and A. Harvey. 1988. Use of a model to optimize the interaction between frequency and severity of intermittent defoliation and to provide a fundamental comparison of the continuous and intermittent defoliation of grass. Grass Forage Sci. 43:49-59. https://doi.org/10.1111/j.1365-2494.1988.tb02140.x.

Patton, D., K. M. Pierce, and B. Horan. 2016. Effect of stocking rate on milk and pasture productivity and supplementary feed use for spring calving pasture fed dairy systems. J. Dairy Sci. 99:59045915. https://doi.org/10.3168/jds.2015-10305.

Peyraud, J. L. 2017. The role of grassland based production system for sustainable protein production. 54. Annual meeting of the Brazilian Society of Animal Science, Foz do Iguaçu, Brasil.

Peyraud, J. L., and R. Delagarde. 2013. Managing variations in dairy cow nutrient supply under grazing. Animal 7(Suppl. S1):57-67. https://doi.org/10.1017/S1751731111002394.

Plantureux, S., A. Bernués, O. Huguenin-Elie, K. Hovstad, J. Isselstein, D. McCracken, O. Therond, and D. Vackar. 2016. Ecosystem services indicators for grassland in relation to ecoclimatic regions and land use systems. Pages 524-547 in Proc. 26th Gen. Mtg. European Grassland Federation, Trondheim, Norway.

Ramsbottom, G., B. Horan, D. P. Berry, and J. R. Roche. 2015. Factors associated with the financial performance of spring-calving, pasture-based dairy farms. J. Dairy Sci. 98:3526-3540. https://doi . org/10.3168/jds.2014-8516.
Roche, J. R., D. P. Berry, A. M. Bryant, C. R. Burke, S. T. Butler, P. G. Dillon, D. J. Donaghy, B. Horan, K. A. Macdonald, and K. L. Macmillan. 2017. A 100-year review: A century of change in temperate grazing dairy systems. J. Dairy Sci. 100:10189-10233. https://doi.org/10.3168/jds.2017-13182.

Roche, J. R., P. Dillon, S. Crosse, and M. Rath. 1996. The effect of closing date of pasture in autumn and turnout date in spring on sward characteristics, dry matter yield and milk production of spring-calving dairy cows. Ir. J. Agric. Food Res. 35:127-140.

Roche, J., L. R. Turner, J. M. Lee, D. C. Edmeades, D. J. Donaghy, K. A. Macdonald, J. W. Penno, and D. P. Berry. 2009. Weather, herbage quality and milk production in pastoral systems. 2. Temporal patterns and intra-relationships in herbage quality and mineral concentration parameters. Anim. Prod. (Purwokerto) 49:200-210. https://doi.org/10.1071/EA07308.

Ryan, W., D. Hennessy, J. J. Murphy, and T. M. Boland. 2010. The effects of autumn closing date on sward leaf area index and herbage mass during the winter period. Grass Forage Sci. 65:200-211.

SAS Institute. 2010. SAS/STAT User's Guide: Statistics. Version 9.3. SAS Institute Inc.

Stott, K. J., and C. J. P. Gourley. 2016. Intensification, nitrogen use and recovery in grazing-based dairy systems. Agric. Syst. 144:101112. https://doi.org/10.1016/j.agsy.2016.01.003.

Teagasc. 2009. Grazing Notebook. Teagasc, Moorepark, Fermoy, Ireland.

Tuñon, G., E. Kennedy, B. Horan, D. Hennessy, N. Lopez-Villalobos, P. Kemp, A. Brennan, and M. O'Donovan. 2014. Effect of grazing severity on perennial ryegrass herbage production and sward structural characteristics throughout an entire grazing season. Grass Forage Sci. 69:104-118. https://doi.org/10.1111/gfs.12048.

Tyrrell, H. F., and J. T. Reid. 1965. Prediction of the energy value of cow's milk. J. Dairy Sci. 48:1215-1223. https://doi.org/10.3168/ jds.S0022-0302(65)88430-2.

Van Soest, P. J. 1963. Use of detergents in the analysis of fibrous feeds. II. A rapid method for the determination of fiber and lignin. J. AOAC 46:829-835.

Wims, C. M., M. H. Deighton, E. Lewis, B. O'Loughlin, L. Delaby, T. M. Boland, and M. O'Donovan. 2010. Effect of pregrazing herbage mass on methane production, dry matter intake, and milk production of grazing dairy cows during the mid-season period. J. Dairy Sci. 93:4976-4985. https://doi.org/10.3168/jds.2010-3245.

\section{ORCIDS}

S. H. Evers @ https://orcid.org/0000-0001-5519-1631

L. Delaby ๑ https://orcid.org/0000-0002-9805-4108

K. M. Pierce @ https://orcid.org/0000-0002-2056-6189

B. Horan @ https://orcid.org/0000-0003-1604-4553 